The Free Internet Journal

for Organic Chemistry
Paper

Arkivoc 2017, part ii, 369-

Organic Chemistry

\title{
Efficient synthesis of differently substituted triarylpyridines with the Suzuki-Miyaura cross-coupling reaction
}

\author{
Dariusz Błachut, ${ }^{a, *}$ Joanna Szawkało, ${ }^{b}$ Piotr Pomarański, ${ }^{b}$ Piotr Roszkowski, ${ }^{b}$ Jan K. Maurin, ${ }^{c, d}$ \\ and Zbigniew Czarnocki ${ }^{b}$ \\ ${ }^{a}$ Forensic Laboratory, Internal Security Agency, 1 Sierpnia 30A, 02-134 Warsaw, Poland \\ ${ }^{b}$ Faculty of Chemistry, University of Warsaw, Pasteura 1, 02-093 Warsaw, Poland \\ ${ }^{c}$ National Medicines Institute, Chełmska 30/34, 00-725 Warsaw, Poland \\ ${ }^{d}$ National Centre for Nuclear Research, 05-400 Otwock-Świerk, Poland \\ E-mail: blachutd@op.pl
}

This paper is dedicated to Professor Jacek Młochowski on the occasion of his $80^{\text {th }}$ birthday

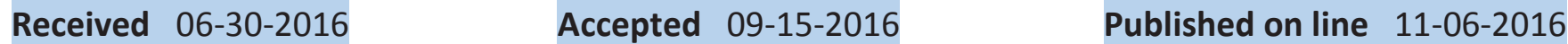

\section{Abstract}

A library of differently substituted 3,4,5-triaryl-2,6-dimethylpyridines and 2,3,5-triaryl-4,6-dimethylpyridines were synthesized and characterized using the Suzuki-Miyaura cross-coupling reaction with accordingly selected tribromodimethylpyridines and arylboronic acids. The optimized coupling conditions were found to be general for both isomeric tribromodimethylpyridines and a wide range of arylboronic acids substituted with electro-donating and electro-withdrawing groups.
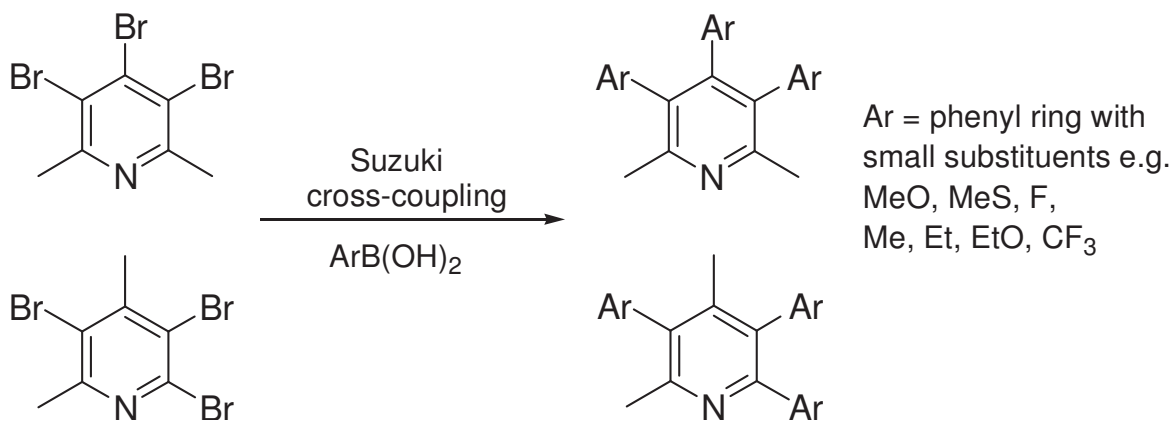

Keywords: Aromatic compounds, arylation, nitrogen heterocycles, forensic chemistry, palladium catalysis 


\section{Introduction}

In recent years, nitrogen heterocycles which contain aryl substituents have received considerable attention due to their importance to various fields of organic chemistry relevant to agricultural, ${ }^{1,2}$ medicinal and pharmaceutical sciences. ${ }^{3-6}$ A typical example is pyridinitril, a well-known fungicide which exhibits the ability to block the action of cytochrome P450-dependent 14a-demethylase, preventing the formation of ergosterol, an important intermediate in the construction of fungal-cell membranes. ${ }^{7-9}$ Many aryl-substituted pyridines are essential building blocks of pharmaceutical agents showing anti-inflammatory, ${ }^{10}$ antibacterial, ${ }^{11}$ and antimalarial $^{12}$ activities. The orally administered antimalarial 3,5-diaryl substituted 2-aminopyridines show promising activity against K1 (chloroquine and drug resistant strain) and NF54 (chloroquine-susceptible strain).$^{13}$ Some polyarylated pyridines were found to be topoisomerase I and II inhibitors exhibiting toxicity toward human tumor cells depending on the nature of the aryl substituents. ${ }^{14,15}$

Our previous studies in forensic chemistry were focused on the identification and synthesis of novel "route-specific" impurities, including dibenzylpyridines $\mathbf{P} \mathbf{1}$ and $\mathbf{P 2}$, and aryl/methylpyridines $\mathbf{P 3}$, and $\mathbf{P 4}$ (Figure 1). ${ }^{16-20}$ We also studied their interesting atropoisomeric properties and we investigated in detail the process of their formation, creating libraries of their 2- and 4-alkoxy and 2- and 4-amino derivatives. ${ }^{21,22}$

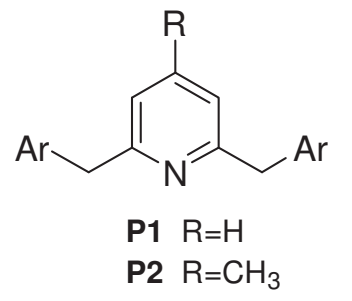<smiles>Cc1nc(C)c(Br)cc1Br</smiles>

P3

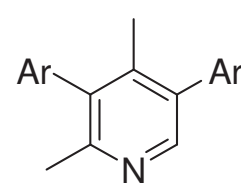

P4<smiles>Cc1nc(C)c(Br)c(Br)c1Br</smiles>

P5<smiles>Cc1nc(Br)c(Br)c(C)c1Br</smiles>

P6

$\mathrm{Ar}=$ phenyl groups with various substituents e.g. $\mathrm{Me}, \mathrm{MeO}, \mathrm{MeS}$, halogens, $\mathrm{CF}_{3}$, EtO, $\mathrm{OCH}_{2} \mathrm{O}$

Figure 1. Structural types of arylated pyridines already investigated by us.

Currently, as a major tool of forensic chemistry in the investigation of the impurity profile of illegally produced amphetamines, gas chromatography coupled with mass spectrometry (GC-MS) is used. ${ }^{23-25}$ This method is routinely applied by us as a "method-of choice" for drugs screening and their "route-specific" markers. Recently, we turned our attention to the presence in the reaction mixtures of several compounds the mass spectra of which were similar to aryl/methylpyridines P3 and P4. More accurate investigation of recorded mass spectra led us to a conclusion that newly discovered compounds may possess general structures of triarylpyridines P5 and P6 (Figure 1). We assumed that the process of their formation may resemble the mechanism of the formation aryl/methylpyridines $\mathbf{P 3}$ and $\mathbf{P 4}$, with one exception that in the condensation and pyridine ring closure sequence a molecule of an arylaldehyde instead of formaldehyde is involved (Scheme 1). 

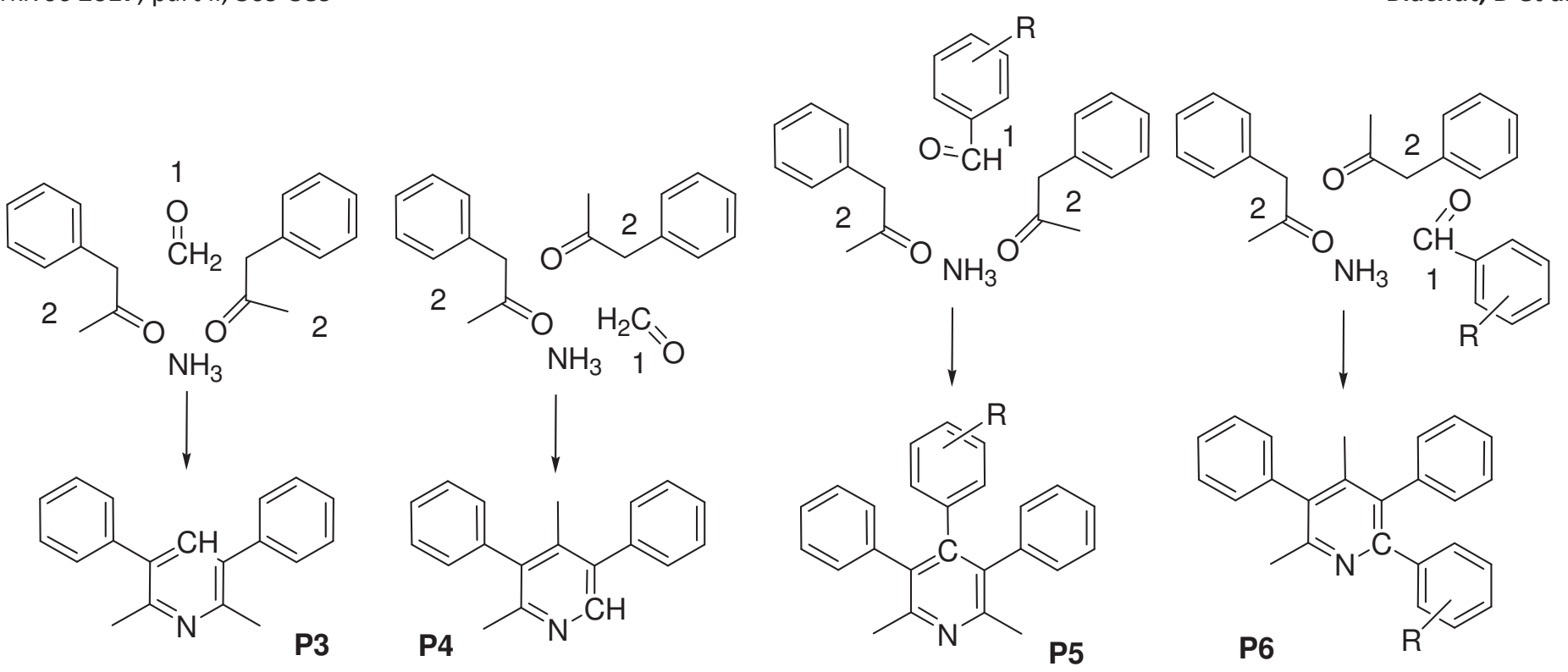

Scheme 1. Building blocks in the formation of pyridines P3, P4, P5, and P6 during synthesis of amphetamine analogues by the Leuckart method. Depending on the arrangement of carbonyl partners, the process proceeds through 2-1-2 or 2-2-1 condensations. ${ }^{26}$

Initially, we reported on the preparation of 2,6-dimethyl-3,4,5-triphenylpyridine 1 a and 2,4-dimethyl3,4,6-triphenylpyridine $2 \mathrm{a}$ by means of Suzuki-Miyaura cross coupling of 4-bromo-2,6-dimethyl-3,5diphenylpyridine and 2-bromo-4,6-dimethyl-3,5-diphenylpyridine with phenylboronic acid in the presence of $\mathrm{Pd}\left[\mathrm{PPh}_{3}\right]_{4}$ as a catalyst and $\mathrm{Na}_{2} \mathrm{CO}_{3}$ as a base. ${ }^{19}$ The major drawback of this method was that it involved de novo preparation of 3,5-diaryldimethylpyridinones from corresponding arylacetones ${ }^{27}$ and dibenzylketones. ${ }^{17,28}$ Both ketones are commercially unavailable and some arylacetones used as precursors of amphetamine analogues remain controlled substances.

We already reported on the preparation of 3,4,5-tris-(2-methoxyphenyl)-2,6-dimethylpyridine from 3,4,5tribromo-2,6-dimethylpyridine 3 via Suzuki reaction with 2-methoxyphenylboronic acid in the presence of palladium acetate and the Buchwald ligand S-Phos. ${ }^{29}$ The positive outcome of this reaction was due to the use of $\mathbf{3}$ as a starting material and careful optimization of the reaction conditions. Considering the easy availability of differently substituted arylboronic acids, our method would be suitable for the preparation of a wide library of 3,4,5-triaryl-2,6-dimethylpyridines P5 (1a-m). Moreover, an analogous approach starting from 2,3,5tribromo-4,6-dimethylpyridine 4 would deliver a number of isomeric 2,3,5-triaryl-4,6-dimethylpyridines P6 (2a-n).

Herein, we report detailed results in the application of the Suzuki-Miyaura cross-coupling reaction leading to a library of pyridines P5 and P6. We also present regioselective syntheses of several 3,5-diarylated 4-, and 2-chlorodimethylpyridines $\mathbf{5}$ and $\mathbf{6}$.

\section{Results and Discussion}

Initially, we prepared the necessary 2,3,5-tribromo-4,6-dimethylpyridine 4 starting from 4,6-dimethylpyridin2-one (Scheme 2). The 3,4,5-tribromo-2,6-dimethylpyridine 3, 3,5-dibromo-4-chloro-2,6-dimethylpyridine 8, 
and 3,5-dibromo-2-chloro-4,6-dimethylpyridine 9 were readily prepared from the corresponding pyridones following previously published procedures. ${ }^{19,29}$

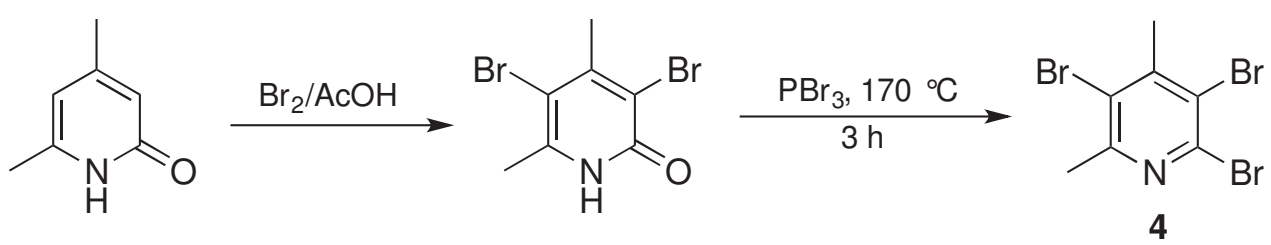

Scheme 2. Synthesis of brominated pyridine 4.

Recently, many examples of full arylation of polyhalogenated heterocycles have been reported. For example, Toguem et al. ${ }^{30}$ described the Suzuki-Miyaura triarylation of 2,3,5-tribromo- $N$-methylpyrrole using 4 mol equivalents of various arylboronic acids in the presence of $\mathrm{Pd}(\mathrm{OAc})_{2}$ and tri(cyclohexyl)phosphine. The authors stated that this catalytic system allowed for much better yields than $\mathrm{Pd}\left[\mathrm{PPh}_{3}\right]_{4}$. Khera et al. ${ }^{31}$ reported tri-fold arylation of 3,4,5-tribromopyrazole using S-Phos and $\mathrm{Pd}(\mathrm{OAc})_{2}$ as catalytic system in the presence of $\mathrm{K}_{2} \mathrm{CO}_{3}$ as a base in the mixture of 1,4-dioxane and water. The yields were good for arylboronic acids containing either electron-withdrawing or electron-donating groups ranging from 70 to $90 \%$. Ibad et al. applied a classical Suzuki cross-coupling catalytic system in triarylation of 2,3,6-tribromo-1-methyl- $1 H$-indole. ${ }^{32}$ The corresponding 2,3,6-triaryl-1-methyl- $1 \mathrm{H}$-indoles were prepared in very good yields from both electron-rich and electron-deficient arylboronic acids in the presence of $\mathrm{Pd}\left[\mathrm{PPh}_{3}\right]_{4}$ in 1,4-dioxane. An efficient procedure leading to variously substituted tetra(styryl)pyridines was published by Ehlers et al. ${ }^{33} \mathrm{~A}$ highly active catalytic system based on the Buchwald ligand X-Phos ${ }^{34-36}$ and $\mathrm{PdCl}_{2}\left(\mathrm{CH}_{3} \mathrm{CN}\right)$ enabled smooth four-fold arylation of readily available 2,3,5,6-tetrachloropyridine. Similar conditions applied to pentachloropyridine yielded a library of pentaarylpyridines with electron-deficient and electron-rich ring systems. ${ }^{37}$ It is interesting to note that the above procedure, when carefully adjusted, gave access to pyridine ring systems with variously substituted aryl substituents. The same group demonstrated the high activity of a catalytic system consisting of $\mathrm{Pd}_{2}(\mathrm{dba})_{3}$ and di(1-adamantyl)-n-butylphosphine as ligand for Suzuki cross coupling of tetrachloropyridine with a wide variety of arylboronic acids. ${ }^{38}$ Also in this case, careful optimization of reaction conditions led to the regioselective step-wise arylation of the pyridine ring system.

In a recent paper we demonstrated that Buchwald ligand S-Phos in connection with palladium donor $\mathrm{Pd}(\mathrm{OAc})_{2}$ in the presence of $\mathrm{K}_{3} \mathrm{PO}_{4}$ allows Suzuki cross-coupling of pyridine $\mathbf{3}$ with 2-methoxyphenylboronic acid in less than an hour. ${ }^{29}$ During an optimization study, this catalytic system proved superior to others, e. $\mathrm{g}$. based on the $\mathrm{Pd}\left[\mathrm{PPh}_{3}\right]_{4}$ or $\mathrm{Pd}(\mathrm{dppf}) \mathrm{Cl}_{2} \times \mathrm{CH}_{2} \mathrm{Cl}_{2}$. In the case of triarylation of $\mathbf{9}$, both catalytic systems led mainly to 4-chloro-3,5-diphenyl-2,6-dimethylpyridine. Similar conditions applied to $\mathbf{3}$ gave a better yield of triarylpyridine, however, the desired product was contaminated with diphenylated pyridines.

At the outset of the present study we decided to test our previously reported conditions for the complete phenylation of 3,5-dibromo-2-chloro-4,6-dimethylpyridine 9 and 2,3,5-tribromo-4,6-dimethylpyridine 4. We expected that the introduction of a chlorine atom at the more electron-deficient and less hindered $\alpha$ position of the pyridine ring would increase the reactivity of $\mathbf{9}$ toward triarylation. In order to verify the usefulness of previously reported conditions for the cross-coupling leading to the desired series of 2,3,5-triaryl-4,6dimethylpyridines, we performed several trial reactions of phenylboronic acid with trihalopyridines $\mathbf{4}$ and $\mathbf{9}$ with the aim of obtaining predominantly the triphenylated product $2 \mathrm{a}$ whilst minimizing the yield of chloropyridine $7^{19}$ and products of mono- and di-phenylation and dehalogenation reactions, shown in Scheme 3 as isomers A, B, C, and D. These compounds were tentatively identified in the reaction mixtures by GC-MS 
analysis. The characteristic isotopic pattern of halogen atoms and the presence of abundant peaks corresponding to molecular ions enabled tentative identification of by-products, but unambiguous assignment of isomers within each particular group (A, B, C, D) was not possible.

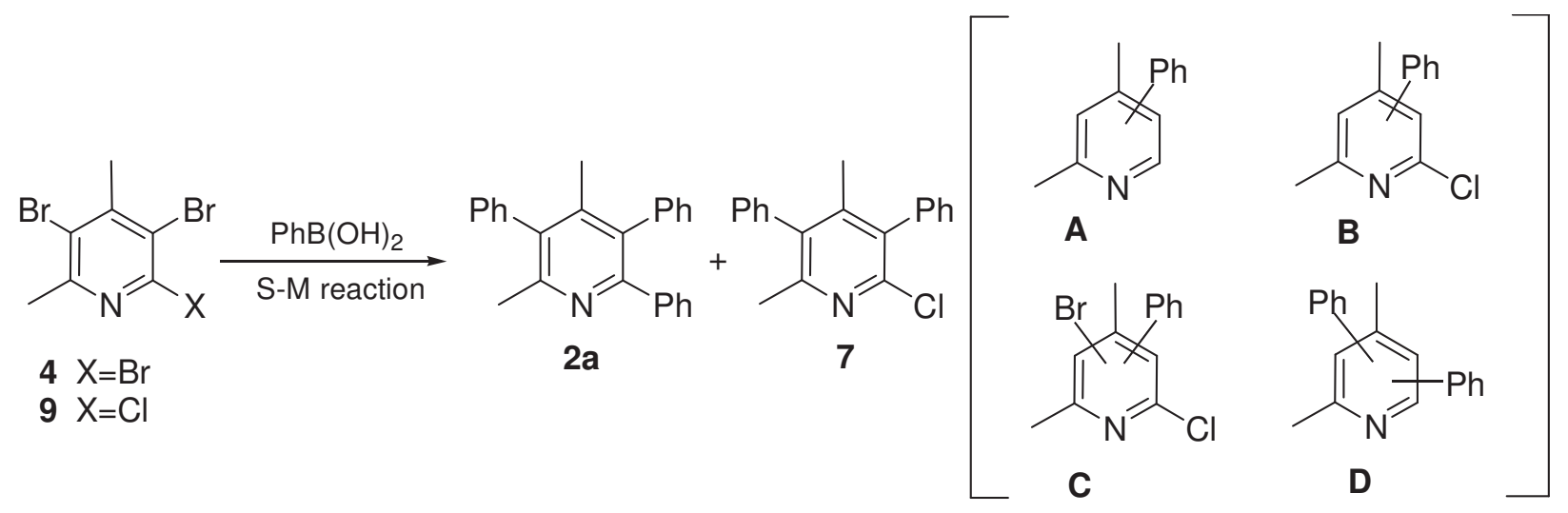

Conditions. 4 or $9\left(5.8 \times 10^{-5} \mathrm{~mol}\right)$, phenylboronic acid (4.2 equiv), solvent system $(2 \mathrm{~mL})$ - toluene, 1,4dioxane, DMF $90{ }^{\circ} \mathrm{C}$; toluene $/ \mathrm{H}_{2} \mathrm{O} / \mathrm{EtOH}, 80^{\circ} \mathrm{C}$. Other details are given in Table 1 and the Experimental section. Identification of by-products A, B, C, and D (in brackets), A - three isomers: 2,4-dimethyl-3-phenylpyridine, 2,4dimethyl-5-phenylpyridine, 2,4-dimethyl-6-phenylpyridine; B - two isomers (only in the case of arylation of 9): 2-chloro-4,6-dimethyl-3-phenylpyridine, 2-chloro-4,6-dimethyl-5-phenylpyridine; C - two isomers (only in the case of arylation of 9): 3-bromo-2-chloro-5-phenyl-4,6-dimethylpyridine, 5-bromo-2-chloro-3-phenyl-4,6dimethylpyridine; D - three isomers: 2,4-dimethyl-3,5-diphenylpyridine, ${ }^{17}$ 2,4-dimethyl-3,6-diphenylpyridine, 2,4-dimethyl-5,6-diphenylpyridine. Regioselective diarylation of 9 (pilot study). Conditions: 9 (1 equiv), phenylboronic acid ( 2.5 equiv), solvent system $(2 \mathrm{~mL})-1,4$-dioxane, DMF $80{ }^{\circ} \mathrm{C}$; acetonitrile $75{ }^{\circ} \mathrm{C}$. Other details are given in Table 2 and the Experimental section.

Scheme 3. Pilot study of triphenylation of $\mathbf{4}$ and $\mathbf{9 .}$

The results of the preliminary reactions are summarized in Table 1.

Application of the classical Suzuki catalytic system based on $\mathrm{Pd}\left[\mathrm{PPh}_{3}\right]$ and $\mathrm{PdCl}_{2}\left[\mathrm{PPh}_{3}\right]_{2}$ in the presence of a medium-strong $\left(\mathrm{Na}_{2} \mathrm{CO}_{3}\right)$ or a weak base $\left(\mathrm{K}_{3} \mathrm{PO}_{4}\right)$ brought about the formation of $2 \mathrm{a}$ in low yield (entries 1-3). The GC-MS analysis indicated significant amounts of chloropyridine 7 and by-products A-C. Interestingly, when more bulky ligand $\mathrm{P}(\mathrm{o} \text {-tol })_{3}$ was used instead of $\mathrm{PPh}_{3}$, the arylation occurred predominantly at 3 and 5 positions of 9 leading selectively to compound 7 in $92 \%$ yield (entry 4). Similar results were obtained when $\mathrm{Pd}(\mathrm{dppf}) \mathrm{Cl}_{2} \times \mathrm{CH}_{2} \mathrm{Cl}_{2}$ (4) and a catalytic system consisting of $\mathrm{Pd}(\mathrm{OAc})_{2} /$ tricyclohexylphosphine was used in the presence of a weak base $\mathrm{K}_{3} \mathrm{PO}_{4}$ (entries 9 and 6, respectively). It was also found that using other bases (entries 5 and 7) and palladium source (entry 8) system based on $\mathrm{P}(\mathrm{Cyc})_{3}$ led again to compound 7 as a main product. The use of ligand system $\mathrm{Pd}(\mathrm{OAc})_{2} / \mathrm{S}$-Phos in toluene improved the coupling significantly. Appropriate selection of the base led to a better yield of the desired triarylated pyridine $2 \mathrm{a}$ ( $85 \%$, entry 11$)$. A similar result was obtained when another Buchwald ligand X-Phos was applied instead of S-Phos (entry 16).

It seems therefore that the reactivity of pyridine derivative 9 is not sufficient thus we turned our attention to pyridine $\mathbf{4}$ as a more promising substrate for the synthesis of pyridines $\mathbf{2}$. Indeed, the reactions with $\mathbf{4}$ were completed in approximately one hour when Buchwald ligand-based catalytic systems (entries 20 and 21) and in two hours for other trials (entries 18 and 19) leading to product $2 a$ in excellent yields of $97 \% / 96 \%$ and $89 \% / 87 \%$, respectively. 
Table 1. Optimization of the triarylation reaction of 9 and $\mathbf{4}$ (Scheme 3); 4.2 equiv. of phenylboronic acid was used

\begin{tabular}{|c|c|c|c|c|c|c|c|c|}
\hline \multirow[b]{2}{*}{ Entry } & \multirow[b]{2}{*}{$\begin{array}{l}\text { Subs- } \\
\text { trate }\end{array}$} & \multirow[b]{2}{*}{ Catalyst } & \multirow[b]{2}{*}{ Base $^{a}$} & \multirow{2}{*}{$\begin{array}{l}\text { Solvent, }{ }^{\mathrm{b}} \text { (time } \\
\text { of reaction), h }\end{array}$} & \multicolumn{4}{|c|}{ Yield, $\%^{d}$} \\
\hline & & & & & $\begin{array}{c}\text { Conver- } \\
\text { sion }^{c}\end{array}$ & $2 a$ & 7 & $\begin{array}{c}\text { By- } \\
\text { products }\end{array}$ \\
\hline 1 & 9 & $\mathrm{Pd}\left[\mathrm{PPh}_{3}\right]_{4}(5)$ & $\mathrm{Na}_{2} \mathrm{CO}_{3}$ & $\begin{array}{c}\text { toluene/ } \mathrm{H}_{2} \mathrm{O} / \\
\text { EtOH (8) }\end{array}$ & 99 & 54 & 42 & 3 \\
\hline 2 & 9 & $\mathrm{PdCl}_{2}\left[\mathrm{PPh}_{3}\right]_{2}(5)$ & $\mathrm{Na}_{2} \mathrm{CO}_{3}$ & $\begin{array}{c}\text { toluene/ } \mathrm{H}_{2} \mathrm{O} / \\
\mathrm{EtOH}(8)\end{array}$ & 98 & 17 & 46 & 35 \\
\hline 3 & 9 & $\mathrm{PdCl}_{2}\left[\mathrm{PPh}_{3}\right]_{2}(5)$ & $\mathrm{K}_{3} \mathrm{PO}_{4}$ & $\begin{array}{c}\text { toluene/ } \mathrm{H}_{2} \mathrm{O} / \\
\mathrm{EtOH}(8)\end{array}$ & 85 & 2 & 31 & 52 \\
\hline 4 & 9 & $\mathrm{Pd}(\mathrm{OAc})_{2}(4), \mathrm{P}(0 \text {-tol })_{3}(8)$ & $\mathrm{Na}_{2} \mathrm{CO}_{3}$ & $\begin{array}{c}\text { toluene/ } \mathrm{H}_{2} \mathrm{O} / \\
\mathrm{EtOH}(8)\end{array}$ & $\sim 100$ & traces & 92 & 8 \\
\hline 5 & 9 & $\mathrm{Pd}(\mathrm{OAc})_{2}(4), \mathrm{P}(\mathrm{Cy})_{3}(12)$ & $\mathrm{Cs}_{2} \mathrm{CO}_{3}$ & toluene (8) & 100 & 35 & 51 & 14 \\
\hline 6 & 9 & $\mathrm{Pd}(\mathrm{OAc})_{2}(4), \mathrm{P}(\mathrm{Cy})_{3}(12)$ & $\mathrm{K}_{3} \mathrm{PO}_{4}$ & toluene (8) & 100 & 6 & 92 & 2 \\
\hline 7 & 9 & $\mathrm{Pd}(\mathrm{OAc})_{2}(4), \mathrm{P}(\mathrm{Cy})_{3}(12)$ & $\mathrm{CsF}$ & toluene (8) & 100 & 7 & 54 & 39 \\
\hline 8 & 9 & $\mathrm{Pd}_{2}(\mathrm{dba})_{3}(4), \mathrm{P}(\mathrm{Cy})_{3}(12)$ & $\mathrm{K}_{3} \mathrm{PO}_{4}$ & toluene (8) & 60 & traces & 24 & 36 \\
\hline 9 & 9 & $\mathrm{Pd}(\mathrm{dppf}) \mathrm{Cl}_{2} \times \mathrm{CH}_{2} \mathrm{Cl}_{2}$ (4) & $\mathrm{K}_{3} \mathrm{PO}_{4}$ & 1,4-dioxane (2) & 100 & 3 & 88 & 9 \\
\hline 10 & 9 & $\mathrm{Pd}(\mathrm{dppf}) \mathrm{Cl}_{2} \times \mathrm{CH}_{2} \mathrm{Cl}_{2}$ (4) & $\mathrm{CsF}$ & 1,4-dioxane (2) & 100 & 11 & 83 & 6 \\
\hline 11 & 9 & $\mathrm{Pd}(\mathrm{OAc})_{2}(4)$, S-Phos (8) & $\mathrm{K}_{3} \mathrm{PO}_{4}$ & toluene (1) & 100 & 85 & 11 & 4 \\
\hline 12 & 9 & $\mathrm{Pd}(\mathrm{OAc})_{2}(4)$, S-Phos (8) & $\mathrm{CsF}$ & toluene (1) & 100 & 69 & 29 & 2 \\
\hline 13 & 9 & $\mathrm{Pd}(\mathrm{OAc})_{2}(4), \mathrm{S}-\mathrm{Phos}(8)$ & $\mathrm{Cs}_{2} \mathrm{CO}_{3}$ & toluene (1) & 100 & 34 & 62 & 4 \\
\hline 14 & 9 & $\mathrm{Pd}(\mathrm{OAc})_{2}(4)$, S-Phos (8) & $\mathrm{K}_{3} \mathrm{PO}_{4}$ & DMF (1) & 100 & 34 & 65 & 1 \\
\hline 15 & 9 & $\mathrm{Pd}(\mathrm{OAc})_{2}(4), \mathrm{S}-\mathrm{Phos}(8)$ & KF & toluene (1) & 100 & 51 & 49 & traces \\
\hline 16 & 9 & $\mathrm{Pd}(\mathrm{OAc})_{2}(4), \mathrm{X}-\mathrm{Phos}(8)$ & $\mathrm{K}_{3} \mathrm{PO}_{4}$ & toluene (1) & 100 & 83 & 13 & 3 \\
\hline 17 & 9 & $\mathrm{Pd}(\mathrm{OAc})_{2}(4), \mathrm{X}-\mathrm{Phos}(8)$ & $\mathrm{CsF}$ & toluene (1) & 100 & 24 & 66 & 9 \\
\hline 18 & 4 & $\mathrm{Pd}(\mathrm{dppf}) \mathrm{Cl}_{2} \times \mathrm{CH}_{2} \mathrm{Cl}_{2}$ (4) & $\mathrm{K}_{3} \mathrm{PO}_{4}$ & dioxane (2) & 100 & 89 & --- & 11 \\
\hline 19 & 4 & $\mathrm{Pd}(\mathrm{OAc})_{2}(4), \mathrm{P}(\mathrm{Cy})_{3}(12)$ & $\mathrm{K}_{3} \mathrm{PO}_{4}$ & toluene (4) & 100 & 87 & --- & 13 \\
\hline 20 & 4 & $\mathrm{Pd}(\mathrm{OAc})_{2}(4), \mathrm{S}-\mathrm{Phos}(8)$ & $\mathrm{K}_{3} \mathrm{PO}_{4}$ & toluene (1) & 100 & 97 & --- & 3 \\
\hline 21 & 4 & $\mathrm{Pd}(\mathrm{OAc})_{2}(4), \mathrm{X}-\mathrm{Phos}(8)$ & $\mathrm{K}_{3} \mathrm{PO}_{4}$ & toluene (1) & 100 & 96 & --- & 4 \\
\hline
\end{tabular}

${ }^{\mathrm{a}} 6$ mol equiv. of base was used. ${ }^{\mathrm{b}}$ Temperatures of reaction: toluene, 1,4-dioxane, DMF, toluene/ $\mathrm{H}_{2} \mathrm{O} 90$ ${ }^{\circ} \mathrm{C}$; solvent system toluene/ $\mathrm{H}_{2} \mathrm{O} / \mathrm{EtOH}, 85{ }^{\circ} \mathrm{C}$. ${ }^{\mathrm{C}}$ The conversion of substrate was measured by GC-MS. It was calculated as a percent ratio of unreacted $\mathbf{4}$ or $\mathbf{9}$ and sum of the peak areas of the $\mathbf{2 a}, \mathbf{7}$ (only for 9) and by-products from groups A, B, C, and D. ${ }^{d}$ the yield was estimated by GC-MS by comparison of peak areas of products with the sum of areas of the rest products and unconverted substrate. ${ }^{\mathrm{e}}$ in calculation of the yield, the sum of peak areas of compounds A, B, C, and D was taken into consideration.

After establishing the optimum conditions (entry 20), the preparation of a library of triaryldimethylpyridines $\mathbf{1 a - m}$ and $\mathbf{2 a - n}$ was then examined using variously substituted arylboronic acids (Scheme 4). 
<smiles>Cc1nc(C)c(Br)c(Br)c1Br</smiles>

3<smiles>Cc1nc(Br)c(Br)c(C)c1Br</smiles>

4

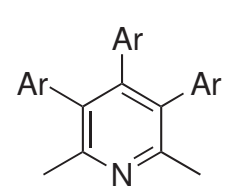

P5

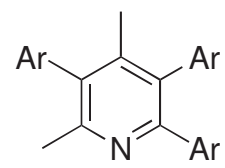

P6
1a $\mathrm{C}_{6} \mathrm{H}_{5}$ 1b $4-\mathrm{MeOC}_{6} \mathrm{H}_{4}$ 1c $2-\mathrm{FC}_{6} \mathrm{H}_{4}$ 1d $3-\mathrm{FC}_{6} \mathrm{H}_{4}$ 1e $4-\mathrm{FC}_{6} \mathrm{H}_{4}$

\section{2a $\mathrm{C}_{6} \mathrm{H}_{5}$} 2b $4-\mathrm{MeOC}_{6} \mathrm{H}_{4}$ 2c $2-\mathrm{FC}_{6} \mathrm{H}_{4}$ 2d $3-\mathrm{FC}_{6} \mathrm{H}_{4}$ 2e $4-\mathrm{FC}_{6} \mathrm{H}_{4}$
94\% 1f $4-\mathrm{MeSC}_{6} \mathrm{H}_{4}$ $73 \% \quad 1 \mathrm{~g} 3,4-\mathrm{OCH}_{2} \mathrm{OC}_{6} \mathrm{H}_{4}$ $45 \%$ 1h $4-\mathrm{MeC}_{6} \mathrm{H}_{4}$ $62 \%$ 1i $4-\mathrm{EtC}_{6} \mathrm{H}_{4}$ $59 \%$ 1j $4-\mathrm{CF}_{3} \mathrm{C}_{6} \mathrm{H}_{4}$
$29 \%$

$49 \%$

$77 \%$

$73 \%$

$59 \%$ 1k $4-\mathrm{EtOC}_{6} \mathrm{H}_{4} \quad 79 \%$ 1l $3-\mathrm{EtOC}_{6} \mathrm{H}_{4} \quad 37 \%$ $1 \mathrm{~m} \mathrm{2-EtOC} \mathrm{H}_{4} \quad 49 \%$

Scheme 4. The synthesis of triaryldimethylpyridines $1 a-1 m$ and $2 a-n$.

Generally, the best yields of final products were obtained for phenylboronic acid and arylboronic acids containing small substituents (methyl, ethyl) in the meta and para position at the phenyl ring. The electronwithdrawing fluorine-containing groups $\left(3-, 4-\mathrm{F}_{2} 4-\mathrm{CF}_{3}\right)$ did not affect the yield of the product, with the exception of ortho-fluoro-substituted products (1c and $\mathbf{2 c}$ ). In the case of 3,4,5-trimethoxyphenyl substituted pyridine (2h) GC-MS analysis indicated the presence of a significant amount of the corresponding biphenyls formed in competing dimerization of the arylboronic acid. Therefore additional portions of boronic reagents were required to complete the coupling. The same procedure was used in the reaction with 4methylthiophenylboronic acid. Prior to final work-up, each of the crude reaction mixtures was examined by GC-MS. In each case two regioisomers (for products 1a-m) and three regioisomers of diaryl-substituted pyridines (for product 2a-n) were observed, however the ratio of products/by-products was different and dependent on the nature of the aryl substituent. All attempts to couple compounds $\mathbf{3}$ or $\mathbf{4}$ with 2-nitro-, 2cyano- and 2-formyl-phenylboronic acids failed. Neither longer reaction time, higher temperature, nor an increased amount of catalyst had noticeable influence on the outcome. We also observed that the yield of pyridines 1 was slightly lower than pyridines $\mathbf{2}$. The higher yields obtained for the coupling of $\mathbf{4}$ can be attributed to the lower steric hindrance present in transition-state in the palladium complex, compared to bulky tribromopyridine 3 .

It is also worthy of note that in the case of compound $1 \mathrm{~m}$ we observed the presence of three components formed in $49 \%$ total yield and in approx. 1:1:1 molar ratio, having the same mass spectra and very similar NMR spectra. We were able to separate them using column chromatography and in two cases we performed an Xray study. Therefore, the stereochemistry of all components was unambiguously established. Thus, the above compounds are atropoisomers which phenomenon arises from the restricted rotation about single $\mathrm{C}_{3,4,5-\text {-prridine }}{ }^{-}$ $\mathrm{C}_{\text {aryl }}$ bonds caused by the steric interaction of the ortho substituents with the neighbouring aryl rings. The first eluting compound during the column chromatography has the structure of $1 \mathrm{~m}$ anti-syn, the second is $1 \mathrm{p}$ antianti atropoisomer, and the third is the complementary stereoisomer $1 \mathrm{~m}$ syn-syn (Figure 2). We have already described a similar phenomenon in the presence of stable atropoisomers of related oligoaryl pyridines. ${ }^{22,29}$ In the case of compound $\mathbf{1} \mathbf{c}$ two diastereomers were detected in the reaction mixture. After their chromatographic separation we recorded their NMR spectra, but apparently due to fast atropoisomerization we were unable to prepare crystals suitable for X-ray study. 


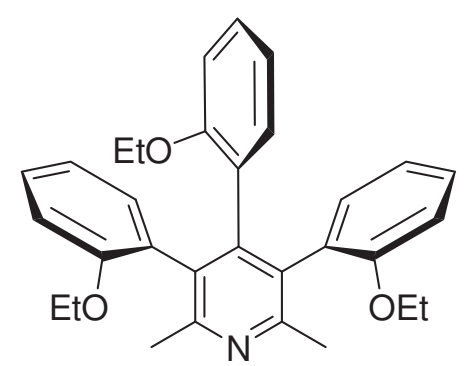

$1 \mathrm{~m}$ anti-syn

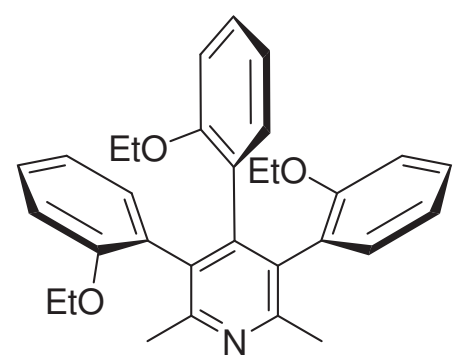

$1 \mathrm{~m}$ anti-anti

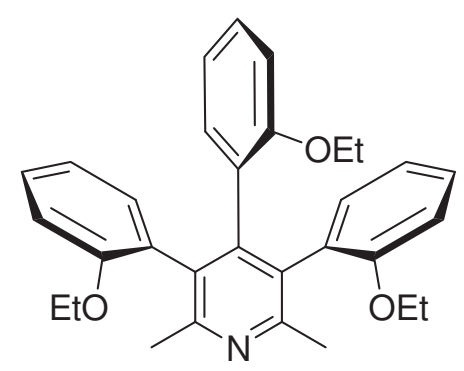

$1 \mathrm{~m}$ syn-syn

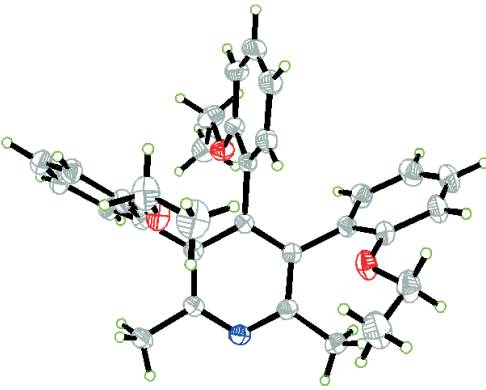

ORTEP $1 \mathrm{~m}$ anti-syn

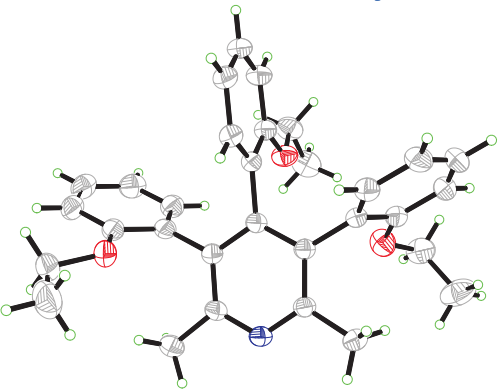

ORTEP 1m anti-anti

Figure 2. The stereochemistry of atropoisomers $1 \mathrm{~m}$.

The crystallographic studies led to some interesting observations. Although both atropoisomers crystallize in the triclinic system, the crystal packing is different. This manifests itself in differences in unit cell volumes (1350.36(6) and 1374.68(14) $\AA^{3}$, respectively) and because of the same unit cell contents results in different calculated crystal densities. The molecular geometries of the compounds are characterized by rotations of rigid fragments (rings) and flexible ethoxy groups. In $1 \mathrm{~m}$ anti-syn all three phenyl rings are not fully perpendicular to the pyridine ring plane. It is worth noting that they are inclined approximately in the same direction - the respective torsion angles are $c a .73^{\circ}, 72^{\circ}$ and $74^{\circ}$. The ethoxy groups are almost co-planar with the respective phenyl rings (torsion angles $c a .193^{\circ}, 178^{\circ}$ and $186^{\circ}$ ) and pointing towards the pyridine ring (respective C-O-C-C torsion angles are ca. $172^{\circ}, 186^{\circ}$ and $182^{\circ}$ ). Similarly in $1 \mathrm{~m}$ anti-anti all phenyl rings are inclined in one direction to the pyridine ring plane forming torsion angles $c a .69^{\circ}, 86^{\circ}$ and $79^{\circ}$. The situation with the ethoxy groups looks a little bit different. Although two of them lie approximately in respective phenyl ring planes the third (on the left in the ORTEPå drawing) is out of plane - the C-O-C-C is ca. $75^{\circ}$. Such distortion is a result of packing forces in the crystal.

Recently we have also been interested in the synthesis of series of pyridines P3/P4 through the regioselective 3,5-diarylation of $\mathbf{8}$ and $\mathbf{9}$ with subsequent dechlorination of intermediary 4-chloro- and 2chloro-3,5-aryldimethylpyridines 5 and $6 .^{19}$ Due to unsatisfactory results there was a need to develop an alternative approach based on the use of the corresponding 3,5-dibrominated 2,4- and 2,6-dimethylpyridines as substrates for the cross-coupling. Our previous results ${ }^{29}$ as well as data collected in Table 1 (entries 4, 6, 9, 
10) indicated that some catalytic systems with a properly chosen base could be suitable for regioselective diarylation of $\mathbf{8}$ and $\mathbf{9}$. In a subsequent study we decided to apply ready to use ferrocenylphosphine-based catalyst $\mathrm{Pd}(\mathrm{dppf}) \mathrm{Cl}_{2} \times \mathrm{CH}_{2} \mathrm{Cl}_{2}$, mainly because of its air stability and high activity. The final synthesis of $\mathbf{5}$ and $\mathbf{6}$ was preceded by optimization of the base and solvent. The results are presented in Table 2.

Table 2. Optimization of the regioselective diarylation of 9 (Scheme 3); 2.5 equiv. of phenylboronic acid was used

\begin{tabular}{|c|c|c|c|c|c|c|c|}
\hline \multirow{2}{*}{ Entry } & \multirow{2}{*}{ Catalyst } & \multirow{2}{*}{ Base $^{a}$} & \multirow{2}{*}{ Solvent ${ }^{b}$} & \multicolumn{4}{|c|}{ Yield, $\%^{d}$} \\
\hline & & & & Conversion $^{c}$ & 7 & $2 a$ & Byproducts $^{\mathrm{e}}$ \\
\hline 1 & $\mathrm{Pd}(\mathrm{dppf}) \mathrm{Cl}_{2} \times \mathrm{CH}_{2} \mathrm{Cl}_{2}$ (4) & CsF & 1,4-dioxane & 100 & 64 & 4 & 32 \\
\hline 2 & $\mathrm{Pd}(\mathrm{dppf}) \mathrm{Cl}_{2} \times \mathrm{CH}_{2} \mathrm{Cl}_{2}$ (4) & $\mathrm{K}_{3} \mathrm{PO}_{4}$ & DMF & 100 & 49 & 18 & 33 \\
\hline 3 & $\mathrm{Pd}(\mathrm{dppf}) \mathrm{Cl}_{2} \times \mathrm{CH}_{2} \mathrm{Cl}_{2}$ (4) & $\mathrm{K}_{3} \mathrm{PO}_{4}$ & $\mathrm{MeCN}$ & $\sim 100$ & 49 & 10 & 52 \\
\hline 4 & $\mathrm{Pd}(\mathrm{dppf}) \mathrm{Cl}_{2} \times \mathrm{CH}_{2} \mathrm{Cl}_{2}$ (4) & $\mathrm{Cs}_{2} \mathrm{CO}_{3}$ & 1,4-dioxane & $\sim 100$ & 73 & 17 & 10 \\
\hline 5 & $\mathrm{Pd}(\mathrm{dppf}) \mathrm{Cl}_{2} \times \mathrm{CH}_{2} \mathrm{Cl}_{2}$ (4) & KF & 1,4-dioxane & 100 & 86 & 6 & 8 \\
\hline 6 & $\mathrm{Pd}(\mathrm{dppf}) \mathrm{Cl}_{2} \times \mathrm{CH}_{2} \mathrm{Cl}_{2}$ (4) & CsF & DMF & $\sim 99$ & 61 & 26 & 12 \\
\hline 7 & $\mathrm{Pd}(\mathrm{dppf}) \mathrm{Cl}_{2} \times \mathrm{CH}_{2} \mathrm{Cl}_{2}$ (4) & $\mathrm{K}_{3} \mathrm{PO}_{4}$ & 1,4-dioxane & 100 & 91 & 3 & 6 \\
\hline
\end{tabular}

a 4 mol equiv. of base was used. ${ }^{b}$ temperature of reaction: 1,4 -dioxane, DMF $80{ }^{\circ} \mathrm{C}$; acetonitrile $75{ }^{\circ} \mathrm{C}$; time of reaction $-3 \mathrm{~h} .{ }^{c}$ the conversion of substrate was measured by GC-MS. It was calculated as a percent ratio of unreacted $\mathbf{9}$ and sum of the peak areas of the $\mathbf{2 a}, \mathbf{6}$ and by-products from groups A, B, C, and D. ${ }^{d}$ the yield was estimated by GC-MS by comparison of peak areas of products with the sum of areas of the rest products and unconverted substrate. ${ }^{\mathrm{e}}$ in calculation of the yields, the sum of peak areas of compound A, B, C, and D was used.

Table 2 clearly shows that the yield of the desired pyridine $\mathbf{7}$ is strongly dependent on the choice of both solvent and base. Various combinations of 1,4-dioxane, DMF and acetonitrile with $\mathrm{CsF}, \mathrm{KF}$ and $\mathrm{Cs}_{2} \mathrm{CO}_{3}$ gave multicomponent product mixtures consistently (GC-MS evidence) and $\mathbf{2}$ a only in moderate yield (entries 1,4 , $5,6)$. The best yield of 2 a was obtained when the combination of mild base and 1,4-dioxane were applied and therefore these conditions were used subsequently for the preparation of a library of pyridines $\mathbf{5}$ and $\mathbf{6}$.

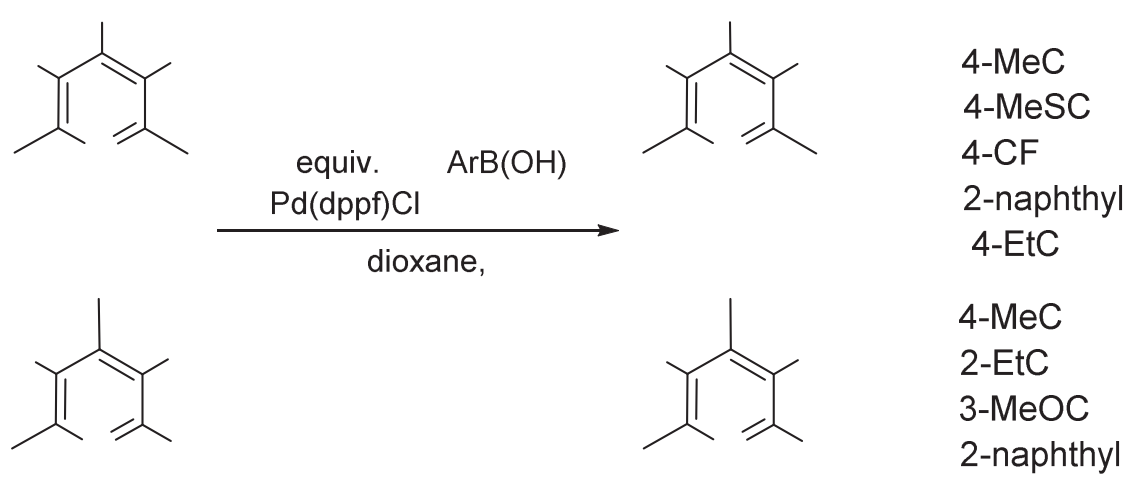

Scheme 5. The regioselective arylation of halopyridines $\mathbf{8}$ and $\mathbf{9 .}$ 
All reactions proceeded in lower yield compared to the pilot study, probably due to competitive formation of monocoupled and debrominated products, indicated by GC-MS analysis. Moreover, difficult isolation and purification of multicomponent crude mixtures decreased the yield of individual compounds. It is noteworthy that all attempts to couple pyridines $\mathbf{8}$ and $\mathbf{9}$ with ortho-substituted arylboronic acids failed completely. Neither diaryl pyridines $\mathbf{8}$ and $\mathbf{9}$ nor even monsubstituted by-products could be detected in the reaction mixtures. Our efforts to react compounds $\mathbf{5}$ and $\mathbf{6}$ with an increased amount of arylboronic acid at elevated temperature (up to $120^{\circ} \mathrm{C}$ ) resulted only in fast formation of the corresponding biphenyls and various dehalogenated dimethylpyridines. To further investigate this phenomenon, the same cross-coupling conditions were applied in the reaction of tribromopyridines 3 and $\mathbf{4}$ with 2-methoxyphenylboronic acid. The GC-MS analysis indicated only traces of the corresponding tri(2-methoxyphenyl)pyridines along with minute amount of its di- and monoaryl/bromo substituted derivatives. This may be explained on the basis of the well accepted mechanism of the palladium-catalysed cross-coupling reaction. ${ }^{39-42}$ The catalytic cycle starts with the oxidative-addition of the aryl halide to a $\mathrm{Pd}(0)$ complex to form arylpalladium(II) halide intermediate. After ligand exchange between the complex and the base, transmetallation with the arylboronic acid occurs followed by reductive elimination leading to the final product. We assume that in our case the reaction is stopped at the stage of transmetallation due to the steric interaction between the bulky ferrocenylphosphine moiety with the ortho-substituent of the arylboronic reagent. Similar problems with arylation of 1,3-dichloro4-iodoisoquinoline with 2-methoxyphenylboronic acid in the presence of $\mathrm{Pd}(\mathrm{dppf}) \mathrm{Cl}_{2} \times \mathrm{CH}_{2} \mathrm{Cl}_{2}$ were reported by Yang. 43

\section{Conclusion}

In summary, a general synthesis of novel 3,4,5- and 2,3,5-triaryl substituted 2,6-and 4,6-dimethylpyridines 1 and 2 in moderate/good yields (29-94\%) has been achieved by palladium/S-Phos mediated coupling of corresponding 3,4,5- and 2,3,5-tribromo substituted dimethylpyridines with a wide array of arylboronic acids. It was also established that cross-coupling with $\mathrm{Pd}(\mathrm{dppf}) \mathrm{Cl}_{2} \times \mathrm{CH}_{2} \mathrm{Cl}_{2}$ as catalyst was selective enough to afford a library of 2- and 4-chloro substituted 3,5-diaryldimethylpyridines 5 and $\mathbf{6}$. Additionally, stable atropoisomers of 2,6-dimethyl-tris(2-ethoxyphenyl)pyridine $1 \mathrm{~m}$ were resolved and their structures were established by X-ray analysis.

\section{Experimental Section}

General. The preparation of 3,4,5-tribromo-2,6-dimethylpyridine 3, 2,3,5-tribromo-4,6-dimethylpyridine 4, 2 chloro-3,5-dibromo-4,6-dimethylpyridine 5, 4-chloro-3,5-dibromo-2,6-dimethylpyridine 6, were carried out by our already reported method. ${ }^{17,19,29}$ The reagents and solvents were commercially available and were used without further purification. All cross-coupling reactions were carried out in $22 \mathrm{~mL}$ vials (Supelco) closed with solid cups sealed with PTFE/silicone septa under argon or nitrogen atmosphere. Thin layer chromatography (TLC) analyses were performed on Merck Kieslgel 60 F-254 plates. The visualization of the plates was done under UV light or with iodine vapor. Evaporation of solvents was performed at reduced pressure, using a Buchi rotary evaporator. Melting points were determined on an Electrothermal, Model IA 9200 apparatus and are uncorrected. NMR spectra were recorded on a Varian Unity Plus spectrometer operating at $200 \mathrm{MHz}$ for ${ }^{1} \mathrm{H}$ NMR and $50 \mathrm{MHz}$ for ${ }^{13} \mathrm{C}$ NMR, respectively or on a Bruker AVANCE $300 \mathrm{MHz}$ spectrometer operating at 300 or 
$500 \mathrm{MHz}$ for ${ }^{1} \mathrm{H}$ NMR and 75 or $125 \mathrm{MHz}$ for ${ }^{13} \mathrm{C}$ NMR, respectively. The following abbreviations are used: $\mathrm{m}-$ multiplet, s-singlet, d-sublet, t-triplet, q-quartet. Low resolution mass spectra were collected on a Agilent Technologies 7000 Triple Quad mass detector coupled with a Agilent Technologies 7890A gas chromatograph. The column HP-5MS $30 \mathrm{~m} \times 0.25 \mathrm{~mm}$ ID, with $0.25 \mu \mathrm{m}$ film thickness was operated at flow rate of $1.5 \mathrm{~mL} / \mathrm{min}$ (helium) and the oven temperature was ramped between $110-340{ }^{\circ} \mathrm{C}$. The mass spectra were recorded in the mass range between 40 and 620 amu. HRMS spectra were collected on Quattro LC Micromass and LCT Micromass TOF HiRes apparatus.

Crystallographic studies were performed for crystals of two compounds: $1 \mathrm{~m}$ anti-syn and 1m anti-anti. Monocrystals suitable for X-ray diffraction studies were obtained from hexane-benzene solutions by slow evaporation of solvents. Good quality crystals were selected and glued to grass capillaries and placed on goniometer heads on the Xcalibur-R single crystal diffractometer from Oxford Diffraction. The diffraction data were collected at room temperature using graphite monochromatized CuK $\alpha$ radiation. The unit cell parameters were obtained by least squares of 8019 and 12857 reflections, respectively. The data were corrected for Lorentz-polarization factor and after solving structures also for absorption. Structures were solved using SHELXS-97 software and refined using SHELXL-97 program. ${ }^{44}$

Crystal data:

$1 \mathrm{~m}$ anti-anti, $\mathrm{C}_{31} \mathrm{H}_{33} \mathrm{NO}_{3}$, Fwt.: 467.58, colourless parallelepiped, size: $0.42 \times 0.37 \times 0.07 \mathrm{~mm}$, triclinic, space group $P-1, a=10.9730(3) \AA, b=11.1132(4) \AA, c=11.5417(4) \AA, \alpha=79.984(3)^{\circ}, \beta=72.209(3)^{\circ}, \gamma=80.924(3)^{\circ}, V$ $=1311.48(7) \AA^{3}, T=293(2) \mathrm{K}, Z=2, F(000)=500, D_{x}=1.184 \mathrm{Mg} / \mathrm{m}^{3}, \mu=0.594 \mathrm{~mm}^{-1}$. Anisotropic refinement on $F^{2}$ for all non $\mathrm{H}$-atoms yielded $R_{1}=0.0420$, and $w R^{2}=0.1267$ for 3792 reflections $[I>2 \sigma(I)]$ with $w=1 /\left[\sigma^{2}\left(F_{o}^{2}\right)+(0.0826 P)^{2}+0.0521 P\right]$ where $P=\left(F_{o}^{2}+2 F_{c}^{2}\right) / 3$. Goodness of fit $=1.063$.

$1 \mathrm{~m}$ anti-syn, $\mathrm{C}_{31} \mathrm{H}_{33} \mathrm{NO}_{3}$, Fwt.: 467.58, colourless parallelepiped, size: $0.76 \times 0.40 \times 0.32 \mathrm{~mm}$, triclinic, space group $P-1, a=8.7527(2) \AA, b=10.0416(3) \AA, c=16.2619(4) \AA, \alpha=102.479(2)^{\circ}, \beta=102.373(2)^{\circ}, \gamma=94.806(2)^{\circ}$, $V=1350.36(6) \AA^{3}, T=293(2) \mathrm{K}, Z=2, F(000)=500, D_{x}=1.150 \mathrm{Mg} / \mathrm{m}^{3}, \mu=0.577 \mathrm{~mm}^{-1}$. Anisotropic refinement on $F^{2}$ for all non $\mathrm{H}$-atoms yielded $R_{1}=0.0509$, and $W R^{2}=0.1599$ for 4244 reflections $[I>2 \sigma(I)]$ with $w=1 /\left[\sigma^{2}\left(F_{o}^{2}\right)+(0.0976 P)^{2}+0.1589 P\right]$ where $P=\left(F_{o}^{2}+2 F_{c}^{2}\right) / 3$. Goodness of fit $=1.073$.

In all structure refinements the hydrogen atoms were included in structure factor calculations in idealized positions but were not refined. The isotropic displacement parameters of hydrogen atoms were approximated from the $U(\mathrm{eq})$ values of atoms to which they were bonded. The detailed information on data collection, structure solution and refinement of the $1 \mathrm{~m}$ anti-anti and anti-syn atropoisomers have been deposited with Cambridge Structural Data Centre under the numbers CCDC 1484433 and CCDC 1486652, respectively.

Experimental and crystallographic refinement data:

\begin{tabular}{|c|c|c|}
\hline Identification code & $1 \mathrm{~m}$ anti-anti & $1 \mathrm{~m}$ anti-syn \\
\hline Deposit number & CCDC 1484433 & CCDC 1486652 \\
\hline Empirical formula & $\mathrm{C}_{31} \mathrm{H}_{33} \mathrm{NO}_{3}$ & $\mathrm{C}_{31} \mathrm{H}_{33} \mathrm{NO}_{3}$ \\
\hline Formula weight & 467.58 & 467.58 \\
\hline Temperature & \multicolumn{2}{|c|}{ 293(2) K } \\
\hline Wavelength & \multicolumn{2}{|c|}{$1.54178 \AA$} \\
\hline Crystal system & Triclinic & Triclinic \\
\hline Space group & $P-1$ & $P-1$ \\
\hline \multirow{3}{*}{ Unit cell dimensions } & $a=10.9730(3) \AA, \alpha=79.984(3)^{\circ}$. & $a=8.7527(2) \AA, \alpha=102.479(2)^{\circ}$. \\
\hline & $b=11.1132(4) \AA, \beta=72.209(3)^{\circ}$ & $\mathrm{b}=10.0416(3) \AA, \beta=102.373(2)^{\circ}$ \\
\hline & $c=11.5417(4) \AA, \gamma=80.924(3)^{\circ}$ & $\mathrm{C}=16.2619(4) \AA, \gamma=94.806(2)^{\circ}$. \\
\hline
\end{tabular}




\begin{tabular}{|c|c|c|}
\hline Volume & $1311.48(7) \AA^{3}$ & $1350.36(6) \AA^{3}$ \\
\hline Z & 2 & 2 \\
\hline Density (calculated) & $1.184 \mathrm{Mg} / \mathrm{m}^{3}$ & $1.150 \mathrm{Mg} / \mathrm{m}^{3}$ \\
\hline Absorption coefficient & $0.594 \mathrm{~mm}^{-1}$ & $0.577 \mathrm{~mm}^{-1}$ \\
\hline$F(000)$ & 500 & 500 \\
\hline Crystal size & $0.4223 \times 0.3696 \times 0.0718 \mathrm{~mm}^{3}$ & $0.7642 \times 0.4000 \times 0.3200 \mathrm{~mm}^{3}$ \\
\hline Theta range for data collection & 4.06 to $70.12^{\circ}$ & 2.87 to $70.20^{\circ}$ \\
\hline Index ranges & $-10 \leq h \leq 13,-13 \leq k \leq 13,-14 \leq 1 \leq 14$ & $-9 \leq h \leq 10,-12 \leq k \leq 12,-19 \leq 1 \leq 19$ \\
\hline Reflections collected & 13552 & 19158 \\
\hline Independent reflections & $4862[R($ int $)=0.0193]$ & $5046[R($ int $)=0.0198]$ \\
\hline Completeness & $97.3 \%$ & $98.1 \%$ \\
\hline Absorption correction & Analytical & Analytical \\
\hline Max. and min. transmission & 0.961 and 0.825 & 0.853 and 0.752 \\
\hline Refinement method & \multicolumn{2}{|c|}{ Full-matrix least-squares on $\mathrm{F}^{2}$} \\
\hline Data / restraints / parameters & $4862 / 0 / 316$ & $5046 / 0 / 316$ \\
\hline Goodness-of-fit on $\mathrm{F}^{2}$ & 1.063 & 1.073 \\
\hline Final $R$ indices [l>2sigma $(I)]$ & $\mathrm{R} 1=0.0420, \mathrm{wR} 2=0.1267$ & $R 1=0.0509, w R 2=0.1599$ \\
\hline$R$ indices (all data) & $R 1=0.0514, w R 2=0.1318$ & $\mathrm{R} 1=0.0570, \mathrm{wR} 2=0.1660$ \\
\hline Largest diff. peak and hole & 0.213 and $-0.181 e \cdot \AA^{-3}$ & 0.257 and $-0.202 e \cdot \AA^{-3}$ \\
\hline
\end{tabular}

\section{2,3,5-Tribromo-4,6-dimethylpyridine (4)}

A mixture of 3,5-dibromo-4,6-dimethylpyridin-2-one (1,45 g, $5.66 \mathrm{mmol})$ and $\mathrm{POBr}_{3}(7.28 \mathrm{~g}, 25.1 \mathrm{mmol})$ was heated at $180^{\circ} \mathrm{C}$ for $1 \mathrm{~h}$. To the cooled mixture, crushed ice and water (ca. $120 \mathrm{~mL}$ ) were added cautiously and the resulting solution was neutralized with solid $\mathrm{NaHCO}_{3}$. The aqueous solution was extracted with $\mathrm{CH}_{2} \mathrm{Cl}_{2}(2 \times$ $20 \mathrm{~mL}$ ) and the combined extracts were dried over $\mathrm{Na}_{2} \mathrm{SO}_{4}$. After evaporation of the solvent the brown solid residue was purified by column chromatography (hexane/EtOAc, 1:0 $\rightarrow$ 10:1) to give pyridine 4 as colorless crystals; yield: $1.12 \mathrm{~g}(63 \%) ; \mathrm{mp} 123-125^{\circ} \mathrm{C}$ lit. ${ }^{45} \mathrm{mp} 124-125^{\circ} \mathrm{C}$. Analytical data according to ref. 45.

Triarylation of pyridines 3 and 4 under Suzuki Conditions. General procedure. Optimization study. A vigorously magnetically stirred mixture of $3(15 \mathrm{mg}, 0.044 \mathrm{mmol})$ or 4 (17 mg, $0.050 \mathrm{mmol})$, phenylboronic acid (4.2 equiv mol, $25.3 \mathrm{mg}$ ), catalytic system (palladium donor and ligand, for quantity see Table 1), base (6 equiv., see Table 1) in $2.5 \mathrm{~mL}$ of solvent system (see Table 1) was heated (oil bath) under argon or nitrogen atmosphere for appropriate time period. The progress of the reaction and ratio of products/intermediates was monitored by removing a sample $(20 \mathrm{~mL})$ of organic layer, which was diluted with toluene $(1 \mathrm{~mL})$, washed with water $\left(2 \mathrm{~mL}\right.$ ) and after drying under anhydrous $\mathrm{Na}_{2} \mathrm{SO}_{4}$ analyzed by GC-MS.

Preparative scale. A solution of pyridine 4 (120 mg, $0.353 \mathrm{mmol})$, palladium acetate (4.0 mol\% equiv.), S-Phos (8.0 mol equiv.) and $\mathrm{K}_{3} \mathrm{PO}_{4}$ (6.0 mol equiv.) and respective arylboronic acid (4.2 mol equiv.) in $15 \mathrm{~mL}$ of toluene was vigorously stirred and heated at $90{ }^{\circ} \mathrm{C}$ (oil bath) under argon atmosphere for 1-4 $\mathrm{h}$. In the case of triarylpyridine $\mathbf{2} \mathrm{h}$, after the reaction mixture had cooled down and additional portion of boronic acids (2.0 equiv.) was added. The heating and stirring was continued for the next $1 \mathrm{~h}$. The reactions were monitored by GC-MS. After completion of the reaction, the mixture was cooled and quenched with cold water (40 $\mathrm{mL})$. The organic layer was extracted with dichloromethane $(3 \times 15 \mathrm{~mL})$. Combined organic part was dried over anhydrous sodium sulfate and concentrated under reduced pressure. The crude mixture was purified by column chromatography on silica gel (230-400 mesh) using hexane/EtOAc mixture in various proportions. 
3,4,5-Triphenyl-2,6-dimethylpyridine (1a). White solid. Yield 94\%, $109 \mathrm{mg}, \mathrm{mp} 113-116{ }^{\circ} \mathrm{C}$, lit. ${ }^{19} \mathrm{mp} 112-115$ ${ }^{\circ} \mathrm{C} .{ }^{1} \mathrm{H}$ NMR $\mathrm{CDCl}_{3}$ ) and ${ }^{13} \mathrm{C} \mathrm{NMR}$ data according to ref. 19. MS, $m / z(\%) 335\left(\mathrm{M}^{+}, 100\right), 320\left(\mathrm{M}^{+}-\mathrm{Me}, 12\right)$.

3,4,5-Tris-(4-methoxyphenyl)-2,6-dimethylpyridine (1b). White solid. Yield 73\%, $108 \mathrm{mg}, \mathrm{mp} 173-176{ }^{\circ} \mathrm{C} .{ }^{1} \mathrm{H}$ NMR $\left(200 \mathrm{MHz}, \mathrm{CDCl}_{3}\right): \delta$ 6.86-6.93 $(\mathrm{m}, 4 \mathrm{H}), 6.68-6.75(\mathrm{~m}, 4 \mathrm{H}), 6.56-6.62(\mathrm{~m}, 2 \mathrm{H}), 6.41-6.46(\mathrm{~m}, 2 \mathrm{H}), 3.74(\mathrm{~s}$, $6 \mathrm{H}), 3.62(\mathrm{~s}, 3 \mathrm{H}), 2.39(\mathrm{~s}, 6 \mathrm{H}) .{ }^{13} \mathrm{C} \mathrm{NMR}\left(50 \mathrm{MHz}, \mathrm{CDCl}_{3}\right): \delta 158.1,157.6,155.0,148.9,133.6,131.6,131.4$,

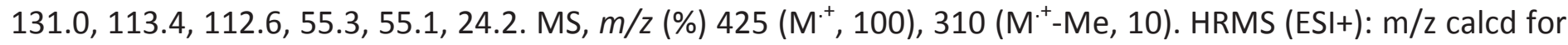
$\mathrm{C}_{28} \mathrm{H}_{28} \mathrm{NO}_{3}[\mathrm{M}+\mathrm{H}]^{+} 426.2069 ;$ found 426.2077 .

3,4,5-Tris-(2-fluorophenyl)-2,6-dimethylpyridine (1c). Pale yellow solid. Yield 45\%, $61 \mathrm{mg}, \mathrm{mp} 111-114{ }^{\circ} \mathrm{C} . \mathrm{MS}$, $\mathrm{m} / z(\%) 389\left(\mathrm{M}^{+}, 100\right), 374\left(\mathrm{M}^{+}-\mathrm{Me}, 13\right)$. Two stable isomers

${ }^{1} \mathrm{H}$ NMR $\left(200 \mathrm{MHz}, \mathrm{CDCl}_{3}\right):$ 8 7.07-7.22 (m, 3H), 6.82-7.05 (m, 7H), 6.58-6.76 (m, 2H), $2.41(\mathrm{~s}, 6 \mathrm{H}) .{ }^{13} \mathrm{C} \mathrm{NMR}(50$ $\mathrm{MHz}_{\mathrm{CDCl}}$ ): $\delta 156.15,132.23,132.20,131.49,131.44,131.26,130.99,130.95,130.12,129.75,129.59$, $129.54,129.38,128.25,125.85,124.17,124.13,124.01,123.94,123.55,123.50,123.45,123.11,123.04$,

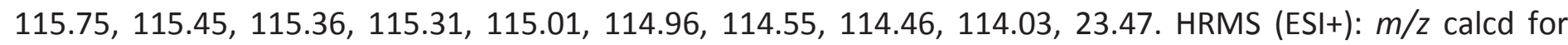
$\mathrm{C}_{25} \mathrm{H}_{19} \mathrm{~F}_{3} \mathrm{~N}[\mathrm{M}+\mathrm{H}]^{+}$390.1470; found 390.1459.

${ }^{1} \mathrm{H}$ NMR (200 MHz, CDCl 3 ): $\delta$ 7.08-7.22 (m, 3H), 6.82-7.05 (m, 7H), 6.58-6.77 (m, 2H), 2.44 and 2.45 (two s, 6H). ${ }^{13} \mathrm{C} \mathrm{NMR}\left(50 \mathrm{MHz}, \mathrm{CDCl}_{3}\right): \delta 156.27,132.23,132.17,131.51,131.46,131.25,130.99,130.95,130.12,129.73$, $129.54,129.38,128.26,124.15,124.10,123.58,123.50,123.10,123.04,122.47,115.75,115.45,115.36$, 115.31, 114.98, 114.94, 114.55, 23.47. HRMS (ESI+): $\mathrm{m} / \mathrm{z}$ calcd for $\mathrm{C}_{25} \mathrm{H}_{19} \mathrm{~F}_{3} \mathrm{~N}[\mathrm{M}+\mathrm{H}]^{+} 390.1470$; found 390.1458.

3,4,5-Tris-(3-fluorophenyl)-2,6-dimethylpyridine (1d). Pale yellow solid. Yield 62\%, $84 \mathrm{mg}, \mathrm{mp} 193-195{ }^{\circ} \mathrm{C} .{ }^{1} \mathrm{H}$ NMR $\left(200 \mathrm{MHz}, \mathrm{CDCl}_{3}\right): \delta 7.12-7.23(\mathrm{~m}, 2 \mathrm{H}), 6.58-6.96(\mathrm{~m}, 8 \mathrm{H}), 6.42-6.53(\mathrm{~m}, 2 \mathrm{H}), 2.41(\mathrm{~s}, 6 \mathrm{H}) .{ }^{13} \mathrm{C} \mathrm{NMR}(50$ $\mathrm{MHz}_{\mathrm{CDCl}}$ ): $\delta 164.8,164.2,159.9,159.3,155.1,147.1,140.5,140.4,139.7,139.6,132.1,129.7,129.6,128.9$, $128.7,125.9,125.8,125.7,125.6,117.2,116.9,116.7,116.5,114.2,113.8,113.7,113.4,23.8 . \mathrm{MS}, \mathrm{m} / \mathrm{z}$ (\%) 389 $\left(\mathrm{M}^{+}, 100\right), 374\left(\mathrm{M}^{+}-\mathrm{Me}, 11\right)$. HRMS (ESI+): $\mathrm{m} / z$ calcd for $\mathrm{C}_{25} \mathrm{H}_{19} \mathrm{~F}_{3} \mathrm{~N}[\mathrm{M}+\mathrm{H}]^{+} 390.1470$; found 390.1479.

3,4,5-Tris-(4-fluorophenyl)-2,6-dimethylpyridine (1e). Pale yellow solid. Yield 59\%, $80 \mathrm{mg}, \mathrm{mp} 218-221{ }^{\circ} \mathrm{C} .{ }^{1} \mathrm{H}$ NMR (200 MHz, CDCl$): \delta 6.84-6.99(\mathrm{~m}, 8 \mathrm{H}), 6.61-6.65(\mathrm{~m}, 4 \mathrm{H}), 2.39(\mathrm{~s}, 6 \mathrm{H}) .{ }^{13} \mathrm{C} \mathrm{NMR}\left(50 \mathrm{MHz}, \mathrm{CDCl}_{3}\right): \delta 164.0$, 163.5, 159.1, 158.6, 155.1, 147.9, 134.5, 134.4, 133.9, 133.8, 132.7, 131.7, 131.6, 131.4, 130.8, 130.7, 115.3, 114.8, 114.5, 114.1, 23.9. MS, $m / z(\%) 389\left(\mathrm{M}^{+}, 100\right), 374\left(\mathrm{M}^{+}-\mathrm{Me}, 11\right)$. HRMS (ESI+): $\mathrm{m} / z$ calcd for $\mathrm{C}_{25} \mathrm{H}_{19} \mathrm{~F}_{3} \mathrm{~N}$ $[\mathrm{M}+\mathrm{H}]^{+} 390.1470$; found 390.1483 .

2,6-Dimethyl-3,4,5-tris-[(4-methylthio)phenyl]pyridine (1f). Pale yellow solid. Yield 29\%, $48 \mathrm{mg}, \mathrm{mp}$ 194-195 ${ }^{\circ} \mathrm{C} .{ }^{1} \mathrm{H}$ NMR $\left(200 \mathrm{MHz}, \mathrm{CDCl}_{3}\right): \delta$ 7.04-7.09 (m, 4H), 6.86-6.93 (m, 4H), 6.75-6.80 (m, 2H), 6.56-6.63 (m, 2H), $2.44(\mathrm{~s}, 6 \mathrm{H}), 2.38(\mathrm{~s}, 6 \mathrm{H}), 2.33(\mathrm{~s}, 3 \mathrm{H}) .{ }^{13} \mathrm{C} \mathrm{NMR}\left(50 \mathrm{MHz}, \mathrm{CDCl}_{3}\right): \delta 155.1,148.2,136.8,136.5,135.6,134.8$,

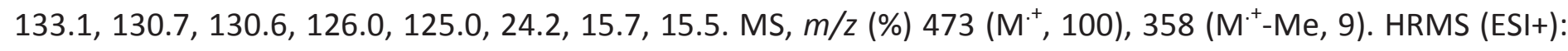
$\mathrm{m} / \mathrm{z}$ calcd for $\mathrm{C}_{28} \mathrm{H}_{28} \mathrm{NS}_{3}[\mathrm{M}+\mathrm{H}]^{+} 474.1384$; found 474.1395 .

2,6-Dimethyl-3,4,5-tris-(3,4-methylenedioxyphenyl)pyridine (1g). Pale brown solid. Yield $49 \%, 80 \mathrm{mg}, \mathrm{mp}$ 202-205 ${ }^{\circ} \mathrm{C} .{ }^{1} \mathrm{H}$ NMR $\left(200 \mathrm{MHz}, \mathrm{CDCl}_{3}\right): \delta 6.64-6.68(\mathrm{~m}, 2 \mathrm{H}), 6.40-6.49(\mathrm{~m}, 5 \mathrm{H}), 6.17-6.23(\mathrm{~m}, 2 \mathrm{H}), 5.91(\mathrm{~s}, 4 \mathrm{H})$, $5.80(\mathrm{~s}, 2 \mathrm{H}), 2.38(\mathrm{~s}, 6 \mathrm{H}) .{ }^{13} \mathrm{C} \mathrm{NMR}\left(50 \mathrm{MHz}, \mathrm{CDCl}_{3}\right): \delta 155.2,148.7,147.4,146.7,146.3,145.8,133.5,132.7$, 132.1, 123.7, 110.6, 108.1, 107.4, 101.1, 100.8, 24.1. MS, $\mathrm{m} / \mathrm{z}$ (\%) $467\left(\mathrm{M}^{+}, 100\right)$. HRMS (ESI+): $\mathrm{m} / \mathrm{z}$ calcd for $\mathrm{C}_{28} \mathrm{H}_{22} \mathrm{NO}_{6}[\mathrm{M}+\mathrm{H}]^{+} 468.1447$; found 468.1455 .

2,6-Dimethyl-3,4,5-tris-(4-methylphenyl)pyridine (1h). White solid. Yield 77\%, $101 \mathrm{mg}, \mathrm{mp} 204-206{ }^{\circ} \mathrm{C} .{ }^{1} \mathrm{H}$ NMR $\left(200 \mathrm{MHz}, \mathrm{CDCl}_{3}\right): \delta 6.85-6.97(\mathrm{~m}, 8 \mathrm{H}), 6.57-6.68(\mathrm{~m}, 4 \mathrm{H}), 2.38(\mathrm{~s}, 6 \mathrm{H}), 2.24(\mathrm{~s}, 6 \mathrm{H}), 2.07(\mathrm{~s}, 3 \mathrm{H}) .{ }^{13} \mathrm{C} \mathrm{NMR}$ $\left(50 \mathrm{MHz}, \mathrm{CDCl}_{3}\right): \delta 154.5,148.7,136.0,135.8,135.3,135.2,133.6,130.0,129.9,128.4,127.5,24.0,21.1,21.0$. MS, $m / z(\%) 377\left(\mathrm{M}^{+}, 100\right), 362\left(\mathrm{M}^{+}-\mathrm{Me}, 8\right)$. HRMS (ESI+): $\mathrm{m} / \mathrm{z}$ calcd for $\mathrm{C}_{28} \mathrm{H}_{28} \mathrm{~N}[\mathrm{M}+\mathrm{H}]^{+} 378.2222$; found 378.2217 
3,4,5-Tris-(4-ethylphenyl)-2,6-dimethylpyridine (1i). White solid. Yield 73\%, $107 \mathrm{mg}, \mathrm{mp} 152-155{ }^{\circ} \mathrm{C} .{ }^{1} \mathrm{H}$ NMR $\left(300 \mathrm{MHz}, \mathrm{CDCl}_{3}\right): \delta$ 6.96-6.99 (m, 4H), 6.87-6.91 (m, 4H), 6.65-6.68 (m, 2H), 6.56-6.60 (m, 2H), $2.54(\mathrm{q}, J=7.5$ $\mathrm{Hz}, 4 \mathrm{H}), 2.40(\mathrm{~s}, 6 \mathrm{H}), 2.37(\mathrm{q}, J=7.5 \mathrm{~Hz}, 2 \mathrm{H}), 1.15(\mathrm{t}, J=7.5 \mathrm{~Hz}, 6 \mathrm{H}), 1.00(\mathrm{t}, J=7.5 \mathrm{~Hz}, 3 \mathrm{H}) .{ }^{13} \mathrm{C} \mathrm{NMR}(75 \mathrm{MHz}$, $\left.\mathrm{CDCl}_{3}\right): \delta 154.7,149.1,142.3,141.8,136.4,135.7,133.8,130.3,130.2,127.3,126.3,28.6,28.5,24.1,15.6$, 15.5. MS, $m / z(\%) 419\left(\mathrm{M}^{+}, 100\right), 390\left(\mathrm{M}^{+}-\mathrm{C}_{2} \mathrm{H}_{5}, 16\right)$. HRMS (ESI+): $\mathrm{m} / \mathrm{z}$ calcd for $\mathrm{C}_{31} \mathrm{H}_{34} \mathrm{~N}[\mathrm{M}+\mathrm{H}]^{+} 420.2691$; found 420.2685 .

3,4,5-Tris-[4-(trifluoromethyl)phenyl]-2,6-dimethylpyridine (1j). White solid. Yield 59\%, $111 \mathrm{mg}, \mathrm{mp} 175-176$ ${ }^{\circ} \mathrm{C} .{ }^{1} \mathrm{H}$ NMR $\left(300 \mathrm{MHz}, \mathrm{CDCl}_{3}\right): \delta$ 7.47-7.51 (m, 4H), 7.19-7.26 (m, 2H), 7.13-7.17 (m, 4H), 6.83-6.86 (m, 2H), $2.42(\mathrm{~s}, 6 \mathrm{H}) .{ }^{13} \mathrm{C} \mathrm{NMR}\left(75 \mathrm{MHz}, \mathrm{CDCl}_{3}\right): \delta$ 155.6, 147.0, 142.07, 142.06, 141.19, 141.17, 132.22, 130.58, 130.32, $129.79,129.47,129.36,129.04,128.93,125.91,125.66,125.35\left(q, J=3.8 \mathrm{~Hz}, \mathrm{CF}_{3}\right), 124.58\left(\mathrm{q}, J=3.8 \mathrm{~Hz}, \mathrm{CF}_{3}\right)$, 122.30, 122.05, 24.1. ${ }^{19} \mathrm{~F} \mathrm{NMR}\left(282 \mathrm{MHz}_{\mathrm{CDCl}}\right.$ ): $\delta$-62.71, -62.89. MS, $m / z(\%) 539\left(\mathrm{M}^{+}, 100\right), 538\left(\mathrm{M}^{+}-\mathrm{H}\right), 520$ $\left(\mathrm{M}^{+}-\mathrm{F}, 18\right)$. HRMS $(\mathrm{ESI}+): \mathrm{m} / z$ calcd for $\mathrm{C}_{28} \mathrm{H}_{19} \mathrm{~F}_{9} \mathrm{~N}[\mathrm{M}+\mathrm{H}]^{+} 540.1374$; found 540.1367 .

3,4,5-Tris-(4-ethoxyphenyl)-2,6-dimethylpyridine (1k). White solid. Yield $79 \%, 129 \mathrm{mg}, \mathrm{mp} 142-143{ }^{\circ} \mathrm{C} .{ }^{1} \mathrm{H}$ NMR $\left(300 \mathrm{MHz}, \mathrm{CDCl}_{3}\right): \delta$ 6.85-6.90 (m, 4H), 6.68-6.72 (m, 4H), 6.55-6.60 (m, 2H), 6.39-6.43 (m, $\left.2 \mathrm{H}\right), 3.95(\mathrm{q}, J$ $=6.9 \mathrm{~Hz}, 4 \mathrm{H}), 3.81(\mathrm{q}, J=6.9 \mathrm{~Hz}, 2 \mathrm{H}), 2.39(\mathrm{~s}, 6 \mathrm{H}), 1.37(\mathrm{t}, J=6.9 \mathrm{~Hz}, 6 \mathrm{H}), 1.29(\mathrm{t}, J=6.9 \mathrm{~Hz}, 3 \mathrm{H}) .{ }^{13} \mathrm{C} \mathrm{NMR}(75$ $\left.\mathrm{MHz}_{\mathrm{CDCl}}\right): \delta 157.5,157.0,154.9,149.0,133.6,131.5,131.43,131.40,130.9,114.0,133.1,63.4,63.2,24.2$, 15.0, 14.9. MS, $m / z(\%) 467\left(\mathrm{M}^{+}, 100\right), 438\left(\mathrm{M}^{+}-\mathrm{C}_{2} \mathrm{H}_{5}, 8\right)$. HRMS (ESI+): $\mathrm{m} / \mathrm{z}$ calcd for $\mathrm{C}_{31} \mathrm{H}_{34} \mathrm{NO}_{3}[\mathrm{M}+\mathrm{H}]^{+}$ 468.2539; found 468.2549 .

3,4,5-Tris-(3-ethoxyphenyl)-2,6-dimethylpyridine (1)). Yield 37\%, $60 \mathrm{mg}$, yellow glassy solid. ${ }^{1} \mathrm{H}$ NMR (300 $\left.\mathrm{MHz}, \mathrm{CDCl}_{3}\right): \delta$ 7.05-7.10 (m, 2H), 6.75-6.81 (m, 1H), 6.54-6.68 (m, 6H), 6.41-6.45 (m, 1H), 6.29-6.35 (m, 2H), 3.77-3.90 (m, 4H), 3.65-3.71 (m, 2H), $2.42(\mathrm{~s}, 6 \mathrm{H}), 1.28-1.33(\mathrm{~m}, 6 \mathrm{H}), 1.21(\mathrm{t}, J=7 \mathrm{~Hz}, 3 \mathrm{H}) .{ }^{13} \mathrm{C} \mathrm{NMR}(75 \mathrm{MHz}$, $\left.\mathrm{CDCl}_{3}\right): \delta 158.5,157.7,154.7,148.4,140.3,139.4,133.4,128.9,128.0,122.9,122.8,116.6,116.4,113.7,113.4$, 63.5, 24.1, 14.9, 14.8. MS, $m / z(\%) 467\left(\mathrm{M}^{+}, 100\right), 438\left(\mathrm{M}^{+}{ }^{+}-\mathrm{C}_{2} \mathrm{H}_{5}, 7\right)$. HRMS (ESI+): $\mathrm{m} / \mathrm{z}$ calcd for $\mathrm{C}_{31} \mathrm{H}_{34} \mathrm{NO}_{3}$ $[\mathrm{M}+\mathrm{H}]^{+} 468.2539 ;$ found 468.2555 .

3,4,5-Tris-(2-ethoxyphenyl)-2,6-dimethylpyridine (1m). Yellow solid. Yield 37\%, $60 \mathrm{mg}$. Three stable isomers.

$1 \mathrm{~m}$ - anti-syn: $\mathrm{mp} 157-158{ }^{\circ} \mathrm{C} ;{ }^{1} \mathrm{H}$ NMR $\left(500 \mathrm{MHz}, \mathrm{CDCl}_{3}\right): \delta$ 7.05-7.08 (m, 2H), 6.93-6.95 (m, 2H), 6.76-6.81 (m, $3 \mathrm{H}), 6.70-6.73(\mathrm{~m}, 3 \mathrm{H}), 6.40-6.44(\mathrm{~m}, 2 \mathrm{H}), 3.94-4.00(\mathrm{~m}, 2 \mathrm{H}), 3.70-3.76(\mathrm{~m}, 4 \mathrm{H}), 2.17(\mathrm{~s}, 6 \mathrm{H}), 1.26(\mathrm{t}, J=7 \mathrm{~Hz}$, $3 \mathrm{H}), 1.21(\mathrm{t}, J=7 \mathrm{~Hz}, 6 \mathrm{H}) .{ }^{13} \mathrm{C} N M R\left(125 \mathrm{MHz}, \mathrm{CDCl}_{3}\right): \delta 155.2,154.4,153.4,146.6,130.3,129.9,128.7,128.5$, $128.1,127.60,127.57,119.4,118.1,111.1,109.6,62.7,62.2,22.8,14.8,14.6 . \mathrm{MS}, \mathrm{m} / \mathrm{z}(\%) 467\left(\mathrm{M}^{+}, 100\right), 438$ $\left(\mathrm{M}^{+}{ }^{-} \mathrm{C}_{2} \mathrm{H}_{5}, 7\right)$. HRMS (ESI+): $\mathrm{m} / z$ calcd for $\mathrm{C}_{31} \mathrm{H}_{34} \mathrm{NO}_{3}[\mathrm{M}+\mathrm{H}]^{+} 468.2539$; found 468.2549.

$1 \mathrm{~m}$ - anti-anti : $\mathrm{mp} 135-136{ }^{\circ} \mathrm{C} ;{ }^{1} \mathrm{H}$ NMR $\left(500 \mathrm{MHz}, \mathrm{CDCl}_{3}\right): \delta$ 7.04-7.09 (m, 2H), 6.87-6.89 (m, 1H), 6.80-6.85 $(\mathrm{m}, 3 \mathrm{H}), 6.73-6.75(\mathrm{~m}, 1 \mathrm{H}), 6.64-6.68(\mathrm{~m}, 2 \mathrm{H}), 6.54-6.57(\mathrm{~m}, 1 \mathrm{H}), 6.43-6.50(\mathrm{~m}, 2 \mathrm{H}), 3.90-4.06(\mathrm{~m}, 4 \mathrm{H}), 3.62-$ $3.69(\mathrm{~m}, 1 \mathrm{H}), 3.40-3.46(\mathrm{~m}, 1 \mathrm{H}), 2.22(\mathrm{~s}, 3 \mathrm{H}), 2.18(\mathrm{~s}, 3 \mathrm{H}), 1.24-1.28(\mathrm{~m}, 6 \mathrm{H}), 1.13(\mathrm{t}, J=7 \mathrm{~Hz}, 3 \mathrm{H}) .{ }^{13} \mathrm{C} \mathrm{NMR}(125$ $\left.\mathrm{MHz}, \mathrm{CDCl}_{3}\right): \delta 155.8,155.3,154.7,153.7,153.6,146.5,137.9,133.4,131.8,130.5,130.4,130.2,130.1,129.7$, $129.3,129.1,128.4,128.1,128.0,127.9,127.4,126.7,126.4,119.6,118.9,118.3,111.0,110.3,62.7,62.2$, 22.8, 14.7, 14.68, 14.2. MS, $m / z(\%) 467\left(\mathrm{M}^{+}, 100\right), 438\left(\mathrm{M}^{+}-\mathrm{C}_{2} \mathrm{H}_{5}, 7\right)$. HRMS (ESI+): $\mathrm{m} / z$ calcd for $\mathrm{C}_{31} \mathrm{H}_{34} \mathrm{NO}_{3}$ $[\mathrm{M}+\mathrm{H}]^{+}$468.2539; found 468.2550.

$1 \mathrm{~m}$ - syn-syn: $\mathrm{mp} 150-151{ }^{\circ} \mathrm{C} ;{ }^{1} \mathrm{H}$ NMR $\left(500 \mathrm{MHz}, \mathrm{CDCl}_{3}\right): \delta$ 7.06-7.09 (m, 2H), 6.80-6.85 (m, 6H), 6.63-6.66 (m, $2 \mathrm{H}), 6.45-6.48(\mathrm{~m}, 1 \mathrm{H}), 6.42-6.43(\mathrm{~m}, 1 \mathrm{H}), 3.89-3.95(\mathrm{~m}, 2 \mathrm{H}), 3.82-3.88(\mathrm{~m}, 2 \mathrm{H}), 3.42(\mathrm{q}, J=7 \mathrm{~Hz}, 2 \mathrm{H}), 3.31(\mathrm{~s}$, $3 \mathrm{H}), 2.21(\mathrm{~s}, 6 \mathrm{H}), 1.19(\mathrm{t}, J=7 \mathrm{~Hz}, 6 \mathrm{H}), 1.05(\mathrm{t}, J=7 \mathrm{~Hz}, 6 \mathrm{H}) .{ }^{13} \mathrm{C} \mathrm{NMR}\left(125 \mathrm{MHz}, \mathrm{CDCl}_{3}\right): \delta$ 155.6, 155.1, 153.6, 146.4, 132.6, 132.0, 130.3, 128.1, 127.9, 127.2, 126.6, 119.0, 117.8, 111.3, 110.6, 62.7, 62.2, 23.1, 14.4, 13.8. MS, $m / z(\%) 467\left(\mathrm{M}^{+}, 100\right), 438\left(\mathrm{M}^{+}{ }_{-}-\mathrm{C}_{2} \mathrm{H}_{5}, 7\right)$. HRMS (ESI+): $\mathrm{m} / z$ calcd for $\mathrm{C}_{31} \mathrm{H}_{34} \mathrm{NO}_{3}[\mathrm{M}+\mathrm{H}]^{+} 468.2539$; found 468.2548 . 


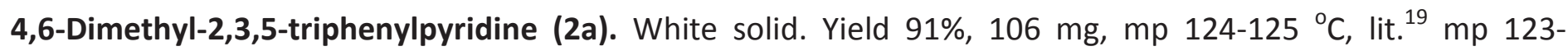
$125^{\circ} \mathrm{C} ; \mathrm{MS}, \mathrm{m} / \mathrm{z}(\%) 334\left(\mathrm{M}^{+}-\mathrm{H}, 100\right), 318\left(\mathrm{M}^{+}{ }^{+} \mathrm{Me}-2 \mathrm{H}, 9\right)$. Analytical data according to [19] $\mathrm{MS}, \mathrm{m} / \mathrm{z}(\%) 334$ $\left(\mathrm{M}^{+}-\mathrm{H}, 100\right), 318\left(\mathrm{M}^{+}-\mathrm{Me}-2 \mathrm{H}, 9\right)$.

2,3,5-Tris-(4-methoxyphenyl)-4,6-dimethylpyridine (2b). White solid. Yield $80 \%, 119 \mathrm{mg}, \mathrm{mp} 124-126^{\circ} \mathrm{C} .{ }^{1} \mathrm{H}$ NMR $\left(200 \mathrm{MHz}_{\mathrm{C}} \mathrm{CDCl}_{3}\right): \delta$ 7.12-7.26 (m, 4H), 6.97-7.04 (m, 4H), 6.79-6.86 (m, 2H), 6.67-6.75 (m, $\left.2 \mathrm{H}\right), 3.87(\mathrm{~s}$, $3 \mathrm{H}), 3.79(\mathrm{~s}, 3 \mathrm{H}), 3.75(\mathrm{~s}, 3 \mathrm{H}), 2.35(\mathrm{~s}, 3 \mathrm{H}), 1.84(\mathrm{~s}, 3 \mathrm{H}) .{ }^{13} \mathrm{C} \mathrm{NMR}\left(50 \mathrm{MHz}, \mathrm{CDCl}_{3}\right): \delta 158.84,158.78,158.5$, 155.5, 155.0, 145.1, 135.2, 134.0, 133.2, 132.1, 131.7, 131.3, 130.4, 114.3, 113.8, 113.2, 55.5, 55.3, 24.2, 19.1. MS, $m / z(\%) 424\left(\mathrm{M}^{+}-\mathrm{H}, 100\right), 425\left(\mathrm{M}^{+}, 61\right), 410\left(\mathrm{M}^{+}-\mathrm{Me}, 11\right)$. HRMS (ESI+): $\mathrm{m} / z$ calcd for $\mathrm{C}_{28} \mathrm{H}_{28} \mathrm{NO}_{3}[\mathrm{M}+\mathrm{H}]^{+}$ 426.2069; found 426.2080.

2,3,5-Tris-(2-fluorophenyl)-4,6-dimethylpyridine (2c). White solid. Yield 53\%, $72 \mathrm{mg}, \mathrm{mp} 126-127{ }^{\circ} \mathrm{C} .{ }^{1} \mathrm{H}$ NMR $\left(300 \mathrm{MHz}, \mathrm{CDCl}_{3}\right): \delta$ 7.36-7.46 $(\mathrm{m}, 1 \mathrm{H}), 7.24-7.35(\mathrm{~m}, 3 \mathrm{H}), 7.14-7.23(\mathrm{~m}, 3 \mathrm{H}), 6.93-7.07(\mathrm{~m}, 4 \mathrm{H}), 6.81-6.87(\mathrm{~m}$, $1 \mathrm{H}), 2.40(\mathrm{~s}, 3 \mathrm{H}), 1.88(\mathrm{~s}, 3 \mathrm{H}) .{ }^{13} \mathrm{C} \mathrm{NMR}\left(75 \mathrm{MHz}, \mathrm{CDCl}_{3}\right): \delta 158.4,158.3,158.1,158.0,156.30,156.25,153.0$, $145.98,145.95,132.24,132.20,132.00,131.96,131.7,131.6,131.48,131.44,131.41,131.37,130.23,130.19$, $130.10,129.99,129.88,129.77,129.64,129.59,129.2,129.1,128.9,128.4,126.5,126.2,125.8,125.6,124.82$, $124.78,124.71,124.67,123.93,123.88,123.86,123.81,123.76,116.4,116.3,116.1,116.0,115.58,115.55$, $115.49,115.28,115.25,115.22,115.19,23.81,23.77,18.18,18.16,18.07 .{ }^{19} \mathrm{~F} \mathrm{NMR}\left(282 \mathrm{MHz}^{\mathrm{C} C D C l}\right)_{3}: \delta-$

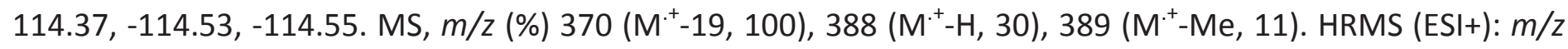
calcd for $\mathrm{C}_{25} \mathrm{H}_{19} \mathrm{~F}_{3} \mathrm{~N}[\mathrm{M}+\mathrm{H}]^{+} 390.1470$; found 390.1476 .

2,3,5-Tris-(3-fluorophenyl)-4,6-dimethylpyridine (2d). White solid. Yield 74\%, $100 \mathrm{mg}, \mathrm{mp} 94-97{ }^{\circ} \mathrm{C} .{ }^{1} \mathrm{H}$ NMR $\left(200 \mathrm{MHz}, \mathrm{CDCl}_{3}\right): \delta$ 7.41-7.53 (m, 1H), 7.21-7.32 (m, 1H), 6.80-7.19 (m, 10H), $2.37(\mathrm{~s}, 3 \mathrm{H}), 1.85(\mathrm{~s}, 3 \mathrm{H}) .{ }^{13} \mathrm{C}$ NMR $\left(50 \mathrm{MHz}_{1} \mathrm{CDCl}_{3}\right): \delta 165.7,165.3,164.9,160.8,160.4,160.1,155.3,154.8,144.5,143.0,142.9,141.5$, $141.4,140.8,140.7,135.2,132.8,130.9,130.7,130.2,130.0,129.4,129.3,126.5,126.4,125.7,125.6,125.1$, $117.8,117.3,117.1,116.7,116.5,116.1,114.9,114.8,114.7,114.5,114.4,114.2,24.1,18.8 . \mathrm{MS}, \mathrm{m} / \mathrm{z}$ (\%) 388 $\left(\mathrm{M}^{+}-\mathrm{H}, 100\right), 389\left(\mathrm{M}^{+}, 11\right), 372\left(\mathrm{M}^{+}-\mathrm{F}, 9\right)$. HRMS $(\mathrm{ESI}+): \mathrm{m} / \mathrm{z}$ calcd for $\mathrm{C}_{25} \mathrm{H}_{19} \mathrm{~F}_{3} \mathrm{~N}[\mathrm{M}+\mathrm{H}]^{+} 390.1470$; found 390.1481.

2,3,5-Tris-(4-methoxyphenyl)-4,6-dimethylpyridine (2b). White solid. Yield 80\%, $119 \mathrm{mg}, \mathrm{mp} 124-126{ }^{\circ} \mathrm{C} .{ }^{1} \mathrm{H}$ NMR $\left(200 \mathrm{MHz}_{\mathrm{CDCl}}\right): \delta$ 7.12-7.26 $(\mathrm{m}, 4 \mathrm{H}), 6.97-7.04(\mathrm{~m}, 4 \mathrm{H}), 6.79-6.86(\mathrm{~m}, 2 \mathrm{H}), 6.67-6.75(\mathrm{~m}, 2 \mathrm{H}), 3.87(\mathrm{~s}$, $3 \mathrm{H}), 3.79(\mathrm{~s}, 3 \mathrm{H}), 3.75(\mathrm{~s}, 3 \mathrm{H}), 2.35(\mathrm{~s}, 3 \mathrm{H}), 1.84(\mathrm{~s}, 3 \mathrm{H}) .{ }^{13} \mathrm{C} \mathrm{NMR}\left(50 \mathrm{MHz}, \mathrm{CDCl}_{3}\right): \delta 158.84,158.78,158.5$, 155.5, 155.0, 145.1, 135.2, 134.0, 133.2, 132.1, 131.7, 131.3, 130.4, 114.3, 113.8, 113.2, 55.5, 55.3, $24.2,19.1$.

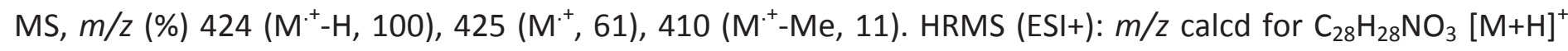
426.2069; found 426.2080 .

2,3,5-Tris-(2-fluorophenyl)-4,6-dimethylpyridine (2c). White solid. Yield 53\%, $72 \mathrm{mg}, \mathrm{mp} 126-127{ }^{\circ} \mathrm{C} .{ }^{1} \mathrm{H} \mathrm{NMR}$ $\left(300 \mathrm{MHz}, \mathrm{CDCl}_{3}\right): \delta$ 7.36-7.46 (m, $\left.1 \mathrm{H}\right), 7.24-7.35(\mathrm{~m}, 3 \mathrm{H}), 7.14-7.23(\mathrm{~m}, 3 \mathrm{H}), 6.93-7.07(\mathrm{~m}, 4 \mathrm{H}), 6.81-6.87(\mathrm{~m}$, $1 \mathrm{H}), 2.40$ (s, 3H), $1.88(\mathrm{~s}, 3 \mathrm{H}) .{ }^{13} \mathrm{C} N M R\left(75 \mathrm{MHz}, \mathrm{CDCl}_{3}\right): \delta$ 158.4, 158.3, 158.1, 158.0, 156.30, 156.25, 153.0, $145.98,145.95,132.24,132.20,132.00,131.96,131.7,131.6,131.48,131.44,131.41,131.37,130.23,130.19$, $130.10,129.99,129.88,129.77,129.64,129.59,129.2,129.1,128.9,128.4,126.5,126.2,125.8,125.6,124.82$, $124.78,124.71,124.67,123.93,123.88,123.86,123.81,123.76,116.4,116.3,116.1,116.0,115.58,115.55$, $115.49,115.28,115.25,115.22,115.19,23.81,23.77,18.18,18.16,18.07 .{ }^{19} \mathrm{~F} \mathrm{NMR}\left(282 \mathrm{MHz}^{\mathrm{C} C D C l}\right)_{3}: \delta-$ 114.37, -114.53, -114.55. MS, $m / z$ (\%) $370\left(\mathrm{M}^{++}-19,100\right), 388\left(\mathrm{M}^{+}-\mathrm{H}, 30\right), 389\left(\mathrm{M}^{++}-\mathrm{Me}, 11\right) . \mathrm{HRMS}(\mathrm{ESI}+): m / z$ calcd for $\mathrm{C}_{25} \mathrm{H}_{19} \mathrm{~F}_{3} \mathrm{~N}[\mathrm{M}+\mathrm{H}]^{+} 390.1470$; found 390.1476.

2,3,5-Tris-(3-fluorophenyl)-4,6-dimethylpyridine (2d). White solid. Yield 74\%, $100 \mathrm{mg}, \mathrm{mp} 94-97{ }^{\circ} \mathrm{C} .{ }^{1} \mathrm{H} \mathrm{NMR}$ $\left(200 \mathrm{MHz} \mathrm{CDCl}_{3}\right): \delta$ 7.41-7.53 (m, 1H), 7.21-7.32 (m, 1H), 6.80-7.19 (m, 10H), $2.37(\mathrm{~s}, 3 \mathrm{H}), 1.85(\mathrm{~s}, 3 \mathrm{H}) .{ }^{13} \mathrm{C}$ NMR $\left(50 \mathrm{MHz}_{1} \mathrm{CDCl}_{3}\right): \delta 165.7,165.3,164.9,160.8,160.4,160.1,155.3,154.8,144.5,143.0,142.9,141.5$, $141.4,140.8,140.7,135.2,132.8,130.9,130.7,130.2,130.0,129.4,129.3,126.5,126.4,125.7,125.6,125.1$, 
$117.8,117.3,117.1,116.7,116.5,116.1,114.9,114.8,114.7,114.5,114.4,114.2,24.1,18.8 . \mathrm{MS}, \mathrm{m} / \mathrm{z}$ (\%) 388 $\left(\mathrm{M}^{+}-\mathrm{H}, 100\right), 389\left(\mathrm{M}^{+}, 11\right), 372\left(\mathrm{M}^{+}-\mathrm{F}, 9\right)$. HRMS (ESI+): $\mathrm{m} / \mathrm{z}$ calcd for $\mathrm{C}_{25} \mathrm{H}_{19} \mathrm{~F}_{3} \mathrm{~N}[\mathrm{M}+\mathrm{H}]^{+} 390.1470$; found 390.1481.

2,3,5-Tris-(4-fluorophenyl)-4,6-dimethylpyridine (2e). White solid. Yield 66\%, $89 \mathrm{mg}, \mathrm{mp} 168-169{ }^{\circ} \mathrm{C} .{ }^{1} \mathrm{H} \mathrm{NMR}$ $\left(200 \mathrm{MHz} \mathrm{CDCl}_{3}\right): \delta 7.18-7.27(\mathrm{~m}, 6 \mathrm{H}), 6.83-7.06(\mathrm{~m}, 6 \mathrm{H}), 2.35(\mathrm{~s}, 3 \mathrm{H}), 1.82(\mathrm{~s}, 3 \mathrm{H}) .{ }^{13} \mathrm{C} \mathrm{NMR}(50 \mathrm{MHz}, \mathrm{CDCl}): \delta$ $164.8,164.7,164.5,159.9,159.8,159.6,155.4,155.2,144.9,137.1,137.0,135.33,135.26,135.1,134.84$, 134.76, 132.9, 132.3, 132.2, 131.8, 131.6, 131.0, 130.8, 116.3, 115.9, 115.8, 115.4, 115.1, 114.6, 24.2, 19.0. MS, $m / z(\%) 388\left(\mathrm{M}^{+}-\mathrm{H}, 100\right), 389\left(\mathrm{M}^{+}, 37\right), 372\left(\mathrm{M}^{+}-\mathrm{F}, 10\right)$. HRMS (ESI+): $\mathrm{m} / z$ calcd for $\mathrm{C}_{25} \mathrm{H}_{19} \mathrm{~F}_{3} \mathrm{~N}[\mathrm{M}+\mathrm{H}]^{+}$ 390.1470; found 390.1483.

4,6-Dimethyl-2,3,5-tris-(4-methylthiophenyl)pyridine (2f). White solid. Yield 37\%, $61 \mathrm{mg}, \mathrm{mp} 150-153{ }^{\circ} \mathrm{C} .{ }^{1} \mathrm{H}$ $\operatorname{NMR}\left(200 \mathrm{MHz}, \mathrm{CDCl}_{3}\right)$ : $\delta$ 7.32-7.37 (m, 2H), 6.98-7.24 (m, 10H), $2.54(\mathrm{~s}, 3 \mathrm{H}), 2.47(\mathrm{~s}, 3 \mathrm{H}), 2.42(\mathrm{~s}, 3 \mathrm{H}), 2.35(\mathrm{~s}$, $3 \mathrm{H}), 1.83(\mathrm{~s}, 3 \mathrm{H}) .{ }^{13} \mathrm{C} N M R\left(50 \mathrm{MHz}, \mathrm{CDCl}_{3}\right): \delta 155.2,155.1,144.8,137.9,137.7,137.6,137.3,136.2,135.6$, $135.3,133.1,131.1,130.4,129.7,127.3,127.1,126.8,126.2,125.8,24.2,19.0,15.8,15.7 . \mathrm{MS}, \mathrm{m} / \mathrm{z}$ (\%) 472 $\left(\mathrm{M}^{+}-\mathrm{H}, 100\right), 473\left(\mathrm{M}^{+}, 56\right)$. HRMS $(\mathrm{ESI}+): \mathrm{m} / z$ calcd for $\mathrm{C}_{28} \mathrm{H}_{28} \mathrm{NS}_{3}[\mathrm{M}+\mathrm{H}]^{+}$474.1384; found 474.1399.

4,6-Dimethyl-2,3,5-tris-(3,4-methylenedioxyphenyl)pyridine (2g). Pale brown solid. Yield 60\%, $98 \mathrm{mg}, \mathrm{mp}$ 211-213 ${ }^{\circ} \mathrm{C} .{ }^{1} \mathrm{H}$ NMR $\left(200 \mathrm{MHz}, \mathrm{CDCl}_{3}\right): \delta 6.87-6.94(\mathrm{~m}, 2 \mathrm{H}), 6.68-6.79(\mathrm{~m}, 4 \mathrm{H}), 6.51-6.66(\mathrm{~m}, 3 \mathrm{H}), 6.03(\mathrm{~s}, 2 \mathrm{H})$, 5.96 (two s, 2H), 5.90 (s, 2H), 2.36 (s, 3H), 1.86 (s, 3H). ${ }^{13} \mathrm{C} \mathrm{NMR}\left(50 \mathrm{MHz}, \mathrm{CDCl}_{3}\right): \delta 155.4,155.1,148.1,147.7$, 147.2, 146.9, 146.6, 145.3, 135.4, 135.3, 133.3, 132.8, 124.0, 124.0, 122.5, 111.0, 110.5, 109.8, 108.9, 108.5, 107.8, 101.3, 101.2, 101.0, 24.1, 18.9. MS, $m / z(\%) 466\left(\mathrm{M}^{+}-\mathrm{H}, 100\right), 467\left(\mathrm{M}^{+}, 72\right)$. HRMS (ESI+): $\mathrm{m} / z$ calcd for $\mathrm{C}_{28} \mathrm{H}_{22} \mathrm{NO}_{6}[\mathrm{M}+\mathrm{H}]^{+} 468.1447$; found 468.1436.

4,6-Dimethyl-2,3,5-tris-(3,4,5-trimethoxyphenyl)pyridine (2h). Pale brown solid. Yield 37\%, $78 \mathrm{mg}, \mathrm{mp} 179-$ $180{ }^{\circ} \mathrm{C} .{ }^{1} \mathrm{H}$ NMR $\left(200 \mathrm{MHz}, \mathrm{CDCl}_{3}\right): \delta 6.61(\mathrm{~s}, 2 \mathrm{H}), 6.46(\mathrm{~s}, 2 \mathrm{H}), 6.36(\mathrm{~s}, 2 \mathrm{H}), 3.94(\mathrm{~s}, 3 \mathrm{H}), 3.88(\mathrm{~s}, 6 \mathrm{H}), 3.84(\mathrm{~s}, 3 \mathrm{H})$, $3.79(\mathrm{~s}, 32 \mathrm{H}), 3.71(\mathrm{~s}, 6 \mathrm{H}), 3.68(\mathrm{~s}, 6 \mathrm{H}) .{ }^{13} \mathrm{C} \mathrm{NMR}\left(50 \mathrm{MHz}, \mathrm{CDCl}_{3}\right): \delta 155.3,155.2,153.8,153.5,152.6,144.8$, 137.6, 137.3, 136.4, 136.1, 135.0, 134.8, 133.6, 108.0, 107.2, 106.1, 61.2, 61.1, 61.0, 56.5, 56.4, 56.1, 24.1, 18.9. MS, $m / z$ (\%) $590\left(\mathrm{M}^{++}-\mathrm{Me}, 100\right), 605\left(\mathrm{M}^{+}, 89\right), 604\left(\mathrm{M}^{+}-\mathrm{H}, 32\right) . \mathrm{HRMS}(\mathrm{ESI}+): \mathrm{m} / z$ calcd for $\mathrm{C}_{34} \mathrm{H}_{40} \mathrm{NO}_{9}$ $[\mathrm{M}+\mathrm{H}]^{+}$606.2703; found 606.2713.

4,6-Dimethyl-2,3,5-tris-(4-methylphenyl)pyridine (2i). White solid. Yield 86\%, $131 \mathrm{mg}, \mathrm{mp} 185-187{ }^{\circ} \mathrm{C} .{ }^{1} \mathrm{H}$ NMR $\left(300 \mathrm{MHz}, \mathrm{CDCl}_{3}\right): \delta$ 7.24-7.28 (m, 2H), 7.16-7.21 (m, 2H), 7.10-7.14 (m, 2H),7.04-7.09 (m, 2H), 6.94-6.99 $(\mathrm{m}, 4 \mathrm{H}), 2.41(\mathrm{~s}, 3 \mathrm{H}), 2.35(\mathrm{~s}, 3 \mathrm{H}), 2.31(\mathrm{~s}, 3 \mathrm{H}), 2.25(\mathrm{~s}, 3 \mathrm{H}), 1.82(\mathrm{~s}, 3 \mathrm{H}) .{ }^{13} \mathrm{C} \mathrm{NMR}\left(75 \mathrm{MHz}, \mathrm{CDCl}_{3}\right): \delta 155.7$, $154.8,144.6,138.5,136.9,136.8,136.7,136.4,135.6,133.7,130.5,129.9,129.6,126.2,129.0,128.8,128.4$, 24.2, 21.5, 21.4, 21.3, 19.0. MS, $m / z(\%) 376\left(\mathrm{M}^{+}-\mathrm{H}, 100\right), 377\left(\mathrm{M}^{+}, 48\right)$. HRMS (ESI+): $m / z$ calcd for $\mathrm{C}_{28} \mathrm{H}_{28} \mathrm{~N}$ $[\mathrm{M}+\mathrm{H}]^{+} 378.2222$; found 378.2213 .

2,3,5-Tris-(4-ethylphenyl)-4,6-dimethylpyridine (2j). White solid. Yield 78\%, $114 \mathrm{mg}, \mathrm{mp} 132-133{ }^{\circ} \mathrm{C} .{ }^{1} \mathrm{H} \mathrm{NMR}$ $\left(300 \mathrm{MHz}, \mathrm{CDCl}_{3}\right): \delta$ 7.27-7.30 (m, 2H), 7.18-7.22 (m, 2H), 7.13-7.17 (m, 2H), 7.07-7.10 (m, 2H), 6.96-7.02 (m, $4 \mathrm{H}), 2.72(\mathrm{q}, J=7.5 \mathrm{~Hz}, 2 \mathrm{H}), 2.62(\mathrm{q}, J=7.5 \mathrm{~Hz}, 2 \mathrm{H}), 2.55(\mathrm{q}, J=7.5 \mathrm{~Hz}, 2 \mathrm{H}), 2.36(\mathrm{~s}, 3 \mathrm{H}), 1.84(\mathrm{~s}, 3 \mathrm{H}), 1.30(\mathrm{t}, J=$ $7.5 \mathrm{~Hz}, 3 \mathrm{H}), 1.21(\mathrm{t}, J=7.5 \mathrm{~Hz}, 3 \mathrm{H}), 1.15(\mathrm{t}, J=7.5 \mathrm{~Hz}, 3 \mathrm{H}) .{ }^{13} \mathrm{C} \mathrm{NMR}\left(75 \mathrm{MHz} \mathrm{CDCl}_{3}\right): \delta 155.7,154.8,144.7$, 143.2, 143.0, 142.7, 138.7, 137.0, 136.5, 135.6, 133.7, 130.6, 129.9, 129.2, 128.3, 127.7, 127.2, 28.78, 28.73, 28.69, 24.2, 19.0, 15.7, 15.6. MS, $m / z(\%) 418\left(\mathrm{M}^{+}-\mathrm{H}, 100\right), 390\left(\mathrm{M}^{+}-\mathrm{C}_{2} \mathrm{H}_{5}, 12\right), 419\left(\mathrm{M}^{+}, 22\right)$. HRMS (ESI+): $\mathrm{m} / z$ calcd for $\mathrm{C}_{31} \mathrm{H}_{34} \mathrm{~N}[\mathrm{M}+\mathrm{H}]^{+} 420.2691$; found 420.2699 .

2,3,5-Tris-[4-(trifluoromethyl)phenyl]-4,6-dimethylpyridine (2k). White solid. Yield 56\%, $105 \mathrm{mg}, \mathrm{mp} 181-182$ ${ }^{\circ} \mathrm{C} .{ }^{1} \mathrm{H}$ NMR $\left(300 \mathrm{MHz}, \mathrm{CDCl}_{3}\right): \delta$ 7.77-7.80 (m, 2H), 7.56-7.59 (m, 2H), 7.36-7.48 (m, 6H), 7.23-7.26 (m, 2H), $2.36(\mathrm{~s}, 3 \mathrm{H}), 1.82(\mathrm{~s}, 3 \mathrm{H}) .{ }^{13} \mathrm{C}$ NMR $\left(75 \mathrm{MHz}, \mathrm{CDCl}_{3}\right): \delta 155.65,154.84,144.43,144.07,144.05,142.93,142.91$, $142.20,142.18,135.40,132.92,131.02,130.45,130.24,130.11,130.05,130.02129 .69,129.62,126.25$ (q, J = $\left.3.8 \mathrm{~Hz}, \mathrm{CF}_{3}\right), 126.11,126.06,126.97,125.68$ ( $\left.\mathrm{q}, \mathrm{J}=3.8 \mathrm{~Hz}, \mathrm{CF}_{3}\right), 125.02\left(\mathrm{q}, J=3.8 \mathrm{~Hz}, \mathrm{CF}_{3}\right), 122.51,122.46$, 
122.37, 24.2, 18.9. ${ }^{19} \mathrm{~F} \mathrm{NMR}\left(282 \mathrm{MHz}, \mathrm{CDCl}_{3}\right): \delta-62.56,-62.58,-62.66 . \mathrm{MS}, \mathrm{m} / \mathrm{z}(\%) 538\left(\mathrm{M}^{+}-\mathrm{H}, 100\right), 539\left(\mathrm{M}^{+}\right.$, 87), $520\left(\mathrm{M}^{+}-\mathrm{F}, 8\right)$. HRMS (ESI+): $\mathrm{m} / z$ calcd for $\mathrm{C}_{28} \mathrm{H}_{19} \mathrm{~F}_{9} \mathrm{~N}[\mathrm{M}+\mathrm{H}]^{+} 540.1374$; found 540.1365 .

2,3,5-tris-(naphthalen-2-yl)-4,6-dimethylpyridine (2l). Pale yellow solid. Yield 49\%, $82 \mathrm{mg}, \mathrm{mp} 208-209{ }^{\circ} \mathrm{C} .{ }^{1} \mathrm{H}$ NMR (300 MHz, $\left.\mathrm{CDCl}_{3}\right)$ : $\delta$ 7.86-7.98 (m, 4H), 7.62-7.77 (m, 7H), 7.49-7.54 (m, 3H), 7.38-7.43 (m, 4H), 7.26-7.34 $(\mathrm{m}, 3 \mathrm{H}), 2.46(\mathrm{~s}, 3 \mathrm{H}), 1.90(\mathrm{~m}, 3 \mathrm{H}) .{ }^{13} \mathrm{C} \mathrm{NMR}\left(75 \mathrm{MHz}, \mathrm{CDCl}_{3}\right): \delta$ 155.8, 155.3, 145.1, 138.7, 137.2, 136.6, 135.9, $134.1,133.8,133.3,133.2,132.7,132.6,132.3,129.61,129.58,128.9,128.8,128.6,128.14,128.09,128.03$, $127.84,127.77,127.55,127.51,127.1,126.6,126.3,126.2,126.1,126.0,125.8,24.4,19.2 . \mathrm{MS}, \mathrm{m} / \mathrm{z}(\%) 484$ $\left(\mathrm{M}^{+}-\mathrm{H}, 100\right), 485\left(\mathrm{M}^{+}, 86\right)$. HRMS (ESI+): $\mathrm{m} / z$ calcd for $\mathrm{C}_{37} \mathrm{H}_{28} \mathrm{~N}[\mathrm{M}+\mathrm{H}]^{+} 486.2222$; found 486.2229 .

2,3,5-Tris-(4-ethoxyphenyl)-4,6-dimethylpyridine (2m). Yield 82\%, $133 \mathrm{mg}$, yellow glassy solid. ${ }^{1} \mathrm{H} \mathrm{NMR}(300$ $\left.\mathrm{MHz}, \mathrm{CDCl}_{3}\right): \delta$ 7.19-7.24 (m, 2H), 7.11-7.16 (m, 2H), 6.99-7.01 (m, 2H), 6.96-6.98 (m, 2H), 6.78-6.82 (m, 2H), 6.67-6.72 (m, 2H), $4.09(\mathrm{q}, J=6.9 \mathrm{~Hz}, 2 \mathrm{H}), 4.00(\mathrm{q}, J=6.9 \mathrm{~Hz}, 2 \mathrm{H}), 3.97(\mathrm{q}, J=6.9 \mathrm{~Hz}, 2 \mathrm{H}), 2.35(\mathrm{~s}, 3 \mathrm{H}), 1.83(\mathrm{~s}$, $\left.3 \mathrm{H}), 1.45(\mathrm{t}, J=6.9 \mathrm{~Hz}, 3 \mathrm{H}), 1.40(\mathrm{t}, J=6.9 \mathrm{~Hz}, 3 \mathrm{H}), 1.36(\mathrm{t}, J=6.9 \mathrm{~Hz}, 3 \mathrm{H}) .{ }^{13} \mathrm{C} \mathrm{NMR}(75 \mathrm{MHz}, \mathrm{CDCl})_{3}\right): \delta 158.2$, $158.1,157.8,155.5,155.0,145.2,135.2,133.8,133.3,131.9,131.7,131.6,131.3,130.4,114.8,114.3,113.8$, 63.6, 63.5, 63.4, 24.2, 19.1, 15.10, 15.04, 15.01. MS, $m / z(\%) 466\left(\mathrm{M}^{+}-\mathrm{H}, 100\right), 467\left(\mathrm{M}^{+}, 77\right), 438\left(\mathrm{M}^{+}-\mathrm{C}_{2} \mathrm{H}_{5}\right.$, 24). HRMS (ESI+): $\mathrm{m} / z$ calcd for $\mathrm{C}_{31} \mathrm{H}_{34} \mathrm{NO}_{3}[\mathrm{M}+\mathrm{H}]^{+} 468.2539$; found 468.2550 .

2,3,5-Tris-(3-ethoxyphenyl)-4,6-dimethylpyridine (2n). Yield 51\%, $83 \mathrm{mg}$, yellow glassy solid. ${ }^{1} \mathrm{H} N M R(300$ $\mathrm{MHz}_{\mathrm{CDCl}}$ ): $\delta$ 7.35-7.40 (m, 1H), 7.14-7.19 (m, 1H), 7.05-7.10 (m, 1H), 6.64-6.94 (m, 9H), 4.07 (q, J=6.9 Hz, $2 \mathrm{H}), 3.92(\mathrm{q}, J=6.9 \mathrm{~Hz}, 2 \mathrm{H}), 3.83(\mathrm{q}, J=6.9 \mathrm{~Hz}, 2 \mathrm{H}), 2.38(\mathrm{~s}, 3 \mathrm{H}), 1.87(\mathrm{~s}, 3 \mathrm{H}), 1.44(\mathrm{t}, J=6.9 \mathrm{~Hz}, 3 \mathrm{H}), 1.32(\mathrm{t}, J=$ $6.9 \mathrm{~Hz}, 3 \mathrm{H}), 1.30$ (t, $J=6.9 \mathrm{~Hz}, 3 \mathrm{H}) .{ }^{13} \mathrm{C} \mathrm{NMR}\left(75 \mathrm{MHz} \mathrm{CDCl}_{3}\right): \delta 159.3,158.7,158.2,155.4,154.6,144.3,142.2$, $140.8,140.3,135.7,133.6,129.9,129.2,128.6,122.9,122.3,121.3,116.6,115.3,115.2,114.5,113.3,63.5$, 63.4, 63.3, 23.9, 18.7, 14.9, 14.8, 14.7. MS, $m / z(\%) 466\left(\mathrm{M}^{+}-\mathrm{H}, 100\right), 467\left(\mathrm{M}^{+}, 52\right), 438\left(\mathrm{M}^{+}-\mathrm{C}_{2} \mathrm{H}_{5}, 21\right) . \mathrm{HRMS}$ $(\mathrm{ESI}+): \mathrm{m} / \mathrm{z}$ calcd for $\mathrm{C}_{31} \mathrm{H}_{34} \mathrm{NO}_{3}[\mathrm{M}+\mathrm{H}]^{+} 468.2539$; found 468.2550 .

\section{Regioselective diarylation of pyridines 8 and 9 under Suzuki conditions. General procedure}

Optimization study: A vigorously magnetically stirred mixture of $\mathbf{8}$ or $\mathbf{9}$ (20 $\mathrm{mg}, 0.067 \mathrm{mmol}$ ), phenylboronic acid (2.5 equiv mol, $20 \mathrm{mg}$ ), $\mathrm{Pd}(\mathrm{dppf}) \mathrm{Cl}_{2} \times \mathrm{CH}_{2} \mathrm{Cl}_{2}$, base (4 equiv., see Table 1 ) in $2.0 \mathrm{~mL}$ of solvent system (see Table 1) was heated (oil bath) under argon or nitrogen atmosphere for appropriate time period. The progress of the reaction and ratio of products/intermediates was monitored by removing a sample (20 $\mathrm{mL})$ of organic layer, which was diluted with toluene $(1 \mathrm{~mL})$, washed with water $(2 \mathrm{~mL})$ and after drying over anhydrous $\mathrm{Na}_{2} \mathrm{SO}_{4}$ analyzed by GC-MS.

Preparative scale: A solution of pyridine 8 or 9 (180 mg, $0.6 \mathrm{mmol}), \mathrm{Pd}(\mathrm{dppf}) \mathrm{Cl}_{2} \times \mathrm{CH}_{2} \mathrm{Cl}_{2}(4 \%$ mol equiv.) and $\mathrm{K}_{3} \mathrm{PO}_{4}$ (4.0 mol equiv.) and respective arylboronic acid (2.5 mol equiv.) in $12 \mathrm{~mL}$ of toluene was vigorously stirred and heated at $80{ }^{\circ} \mathrm{C}$ (oil bath) under argon atmosphere for $3 \mathrm{~h}$. The reactions were monitored by GCMS. After completion of the reaction, the mixture was cooled and quenched with cold water $(50 \mathrm{~mL})$. The organic layer was extracted with $\mathrm{CH}_{2} \mathrm{Cl}_{2}(3 \times 15 \mathrm{~mL})$. The combined organic extracts were dried over anhydrous $\mathrm{Na}_{2} \mathrm{SO}_{4}$ and concentrated under reduced pressure. The crude mixture was purified by column chromatography on silica gel (230-400 mesh) using hexane/EtOAc mixture in various proportions.

4-Chloro-3,5-bis-(4-methylphenyl)-2,6-dimethylpyridine (5a). Pale yellow solid. Yield 69\%, $133 \mathrm{mg}, \mathrm{mp} 179-$ $180{ }^{\circ} \mathrm{C} .{ }^{1} \mathrm{H}$ NMR $\left(300 \mathrm{MHz}, \mathrm{CDCl}_{3}\right): \delta$ 7.24-7.28 (m, 4H), 7.11-7.14 (m, 4H), $2.41(\mathrm{~s}, 6 \mathrm{H}), 2.33(\mathrm{~s}, 6 \mathrm{H}) .{ }^{13} \mathrm{C} \mathrm{NMR}(75$ $\left.\mathrm{MHz}_{2} \mathrm{CDCl}_{3}\right): \delta 156.2,143.3,173.7,134.7,133.4,129.5,129.4,24.2,21.5 . \mathrm{MS}, \mathrm{m} / \mathrm{z}(\%) 321\left(\mathrm{M}^{+}, 100\right), 306\left(\mathrm{M}^{+}{ }_{-}\right.$ $\mathrm{Me}, 17)$. HRMS (ESI+): $\mathrm{m} / z$ calcd for $\mathrm{C}_{21} \mathrm{H}_{21} \mathrm{CIN}[\mathrm{M}+\mathrm{H}]^{+} 322.1363$; found 322.1372 .

4-Chloro-3,5-bis-[4-(methylthio)phenyl]-2,6-dimethylpyridine (5b). Yellow solid. Yield $120 \mathrm{mg}$ (52\%), mp 148$149{ }^{\circ} \mathrm{C} .{ }^{1} \mathrm{H}$ NMR $\left(300 \mathrm{MHz}, \mathrm{CDCl}_{3}\right): \delta 7.31-7.35(\mathrm{~m}, 4 \mathrm{H}), 7.13-7.18(\mathrm{~m}, 4 \mathrm{H}), 2.53(\mathrm{~s}, 6 \mathrm{H}), 2.34(\mathrm{~s}, 6 \mathrm{H}) .{ }^{13} \mathrm{C} \mathrm{NMR}$ $\left(75 \mathrm{MHz} \mathrm{CDCl}_{3}\right): \delta 156.1,143.1,138.3,133.9,132.8,129.8,126.3,24.0,15.5 . \mathrm{MS}, \mathrm{m} / \mathrm{z}(\%) 385\left(\mathrm{M}^{+}, 100\right), 370$ (M+ $\left.{ }^{+}-\mathrm{Me}, 9\right)$. HRMS (ESI+): $\mathrm{m} / z$ calcd for $\mathrm{C}_{21} \mathrm{H}_{21} \mathrm{CINS}_{2}[\mathrm{M}+\mathrm{H}]^{+} 386.0804$; found 386.0813 . 
4-Chloro-3,5-bis-[4-(trifluoromethyl)phenyl]-2,6-dimethylpyridine (5c). Yellow solid. Yield 60\%, $155 \mathrm{mg}, \mathrm{mp}$ 157-158 ${ }^{\circ} \mathrm{C} .{ }^{1} \mathrm{H}$ NMR $\left(300 \mathrm{MHz}, \mathrm{CDCl}_{3}\right): \delta$ 7.72-7.76 (m, 4H) 7.37-7.40 (m, 4H), $2.34(\mathrm{~s}, 6 \mathrm{H}) .{ }^{13} \mathrm{C} \mathrm{NMR}(75 \mathrm{MHz}$, $\left.\mathrm{CDCl}_{3}\right): \delta 156.4,142.5,140.7,132.3,130.5,130.1,129.9,129.7,129.5,127.1,125.7\left(\mathrm{q}, J=3.8 \mathrm{~Hz}, \mathrm{CF}_{3}\right), 125.5$, 122.2, 115.6, 23,9. ${ }^{19} \mathrm{~F}$ NMR (282 MHz, CDCl $): \delta-62.61 . \mathrm{MS}, \mathrm{m} / \mathrm{z}(\%) 429\left(\mathrm{M}^{+}, 100\right), 428\left(\mathrm{M}^{+{ }^{+}}-\mathrm{H}, 96\right), 410\left(\mathrm{M}^{+{ }^{+}}-\mathrm{F}\right.$, 18). HRMS (ESI+): $\mathrm{m} / z$ calcd for $\mathrm{C}_{21} \mathrm{H}_{15} \mathrm{ClF}_{6} \mathrm{~N}[\mathrm{M}+\mathrm{H}]^{+} 430.0797$; found 430.0809 .

4-chloro-3,5-bis-(naphthalen-2-yl)-2,6-dimethylpyridine (5d). Yield 63\%, $195 \mathrm{mg}$, yellow glassy solid. ${ }^{1} \mathrm{H}$ NMR $\left(300 \mathrm{MHz}, \mathrm{CDCl}_{3}\right): \delta$ 7.84-7.95 (m, 5H), 7.75-7.77 (m, 2H), 7.48-7.53 (m, 5H), 7.36-7.40 (m, 2H), $2.41(\mathrm{~s}, 6 \mathrm{H}) .{ }^{13} \mathrm{C}$ $\operatorname{NMR}\left(75 \mathrm{MHz}_{\mathrm{CDCl}}\right.$ ): $\delta$ 156.4, 135.0, 133.6, 133.5, 132.9, 128.7, 128.5, 128.3, 128.0, 127.4, 126.6, 24.2. MS, $m / z(\%) 393\left(\mathrm{M}^{+}, 100\right), 392\left(\mathrm{M}^{+}-\mathrm{H}, 31\right)$. HRMS (ESI+): $\mathrm{m} / z$ calcd for $\mathrm{C}_{27} \mathrm{H}_{21} \mathrm{CIN}[\mathrm{M}+\mathrm{H}]^{+} 394.1363$; found 394.1369.

4-Chloro-3,5-bis-(4-ethylphenyl)-2,6-dimethylpyridine (5e). Yellow solid. Yield 74\%, $155 \mathrm{mg}, \mathrm{mp} 117-118{ }^{\circ} \mathrm{C}$. ${ }^{1} \mathrm{H}$ NMR $\left(300 \mathrm{MHz} \mathrm{CDCl}_{3}\right): \delta$ 7.26-7.30 (m, 4H), 7.13-7.17 (m, 4H), $2.71(\mathrm{q}, J=7.5 \mathrm{~Hz}, 4 \mathrm{H}), 2.34(\mathrm{~s}, 6 \mathrm{H}), 1.29(\mathrm{t}, J$ $=7.5 \mathrm{~Hz}, 6 \mathrm{H}) .{ }^{13} \mathrm{C} \mathrm{NMR}\left(75 \mathrm{MHz}_{\mathrm{CDCl}}\right): \delta 156.0,143.6,143.1,134.7,133.3,129.2,128.0,28.6,24.0,15.2 . \mathrm{MS}$, $m / z(\%) 349\left(\mathrm{M}^{+}, 100\right), 334\left(\mathrm{M}^{++}-\mathrm{Me}, 48\right), 320\left(\mathrm{M}^{+}-\mathrm{C}_{2} \mathrm{H}_{5}, 17\right)$. HRMS (ESI+): $\mathrm{m} / z$ calcd for $\mathrm{C}_{23} \mathrm{H}_{25} \mathrm{CIN}[\mathrm{M}+\mathrm{H}]^{+}$ 350.1676; found 350.1685.

2-Chloro-3,5-bis-(4-methylphenyl)-4,6-dimethylpyridine (6a). Pale yellow solid. Yield 49\%, $95 \mathrm{mg}, \mathrm{mp} 171-172$ ${ }^{\circ} \mathrm{C} .{ }^{1} \mathrm{H}$ NMR $\left(300 \mathrm{MHz}, \mathrm{CDCl}_{3}\right): \delta$ 7.24-7.28 (m, 4H), 7.10-7.14 (m, 2H), 7.03-7.07 (m, 2H), $2.40(\mathrm{~s}, 6 \mathrm{H}), 2.28(\mathrm{~s}$, $3 \mathrm{H}), 1.78(\mathrm{~s}, 3 \mathrm{H}) .{ }^{13} \mathrm{C} \mathrm{NMR}\left(75 \mathrm{MHz}, \mathrm{CDCl}_{3}\right): \delta 155.7,148.5,147.6,137.6,137.4,136.4,135.5,134.7,134.1$,

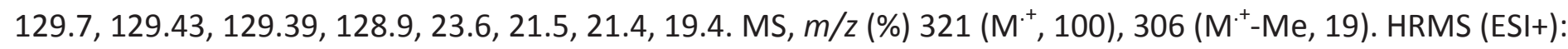
$\mathrm{m} / z$ calcd for $\mathrm{C}_{21} \mathrm{H}_{21} \mathrm{CIN}[\mathrm{M}+\mathrm{H}]^{+} 322.1363$; found 322.1375 .

2-Chloro-3,5-bis-(4-ethylphenyl)-4,6-dimethylpyridine (6b). White solid. Yield 52\%, $109 \mathrm{mg}, \mathrm{mp} 118-119{ }^{\circ} \mathrm{C}$. ${ }^{1} \mathrm{H}$ NMR $\left(300 \mathrm{MHz}, \mathrm{CDCl}_{3}\right): \delta 7.26-7.30(\mathrm{~m}, 4 \mathrm{H}), 7.13-7.17(\mathrm{~m}, 2 \mathrm{H}), 7.05-7.09(\mathrm{~m}, 2 \mathrm{H}), 2.71(\mathrm{q}, J=7.5 \mathrm{~Hz}, 4 \mathrm{H})$, $2.28(\mathrm{~s}, 3 \mathrm{H}), 1.78(\mathrm{~s}, 3 \mathrm{H}), 1.29(\mathrm{t}, J=7.5 \mathrm{~Hz}, 6 \mathrm{H}) .{ }^{13} \mathrm{C} \mathrm{NMR}\left(75 \mathrm{MHz}, \mathrm{CDCl}_{3}\right): \delta 155.7,148.5,147.6,143.9,143.7$, $136.4,135.7,134.9,1341,129.5,129.0,128.5,128.2,28.8,28.7,23.6,19.5,15.5,15.4 . \mathrm{MS}, \mathrm{m} / \mathrm{z}(\%) 349\left(\mathrm{M}^{+}\right.$, 100), $334\left(\mathrm{M}^{+}-\mathrm{Me}, 36\right), 320\left(\mathrm{M}^{+}-\mathrm{C}_{2} \mathrm{H}_{5}, 8\right)$. HRMS (ESI+): $\mathrm{m} / z$ calcd for $\mathrm{C}_{23} \mathrm{H}_{25} \mathrm{NCl}[\mathrm{M}+\mathrm{H}]^{+} 350.1676$; found 350.1688.

2-Chloro-3,5-bis-(3-methoxyphenyl)-4,6-dimethylpyridine (6c). White solid. Yield 43\%, $91 \mathrm{mg}, \mathrm{mp} 148-149{ }^{\circ} \mathrm{C}$. ${ }^{1} \mathrm{H}$ NMR $\left(300 \mathrm{MHz}, \mathrm{CDCl}_{3}\right): \delta$ 7.35-7.41 (m, 2H), 6.91-6.97 (m, 2H), 6.71-6.84 (m, 4H), $3.83(\mathrm{~s}, 6 \mathrm{H}), 2.30(\mathrm{~s}, 3 \mathrm{H})$, 1.81 (s, 3H). ${ }^{13} \mathrm{C}$ NMR $\left(75 \mathrm{MHz} \mathrm{CDCl}_{3}\right): \delta 159.9,159.7,155.5,148.2,147.1,139.6,138.7,136.1,133.8,130.0$, 129.7, 121.7, 121.2, 115.1, 114.6, 113.2, 112.9, 55.3, 23.3, 19.0. MS, m/z (\%) $353\left(\mathrm{M}^{++}, 100\right), 322\left(\mathrm{M}^{+}-\mathrm{MeO}\right.$ 17), $338\left(\mathrm{M}^{+}-\mathrm{Me}, 8\right)$. HRMS (ESI+): $\mathrm{m} / z$ calcd for $\mathrm{C}_{21} \mathrm{H}_{21} \mathrm{NO}_{2} \mathrm{Cl}[\mathrm{M}+\mathrm{H}]^{+} 354.1261$; found 354.1275.

2-Chloro-3,5-bis(naphthalen-2-yl)-4,6-dimethylpyridine (6d). Yield 38\%, $90 \mathrm{mg}$, pale yellow oil. ${ }^{1} \mathrm{H} \mathrm{NMR}(300$ $\left.\mathrm{MHz}, \mathrm{CDCl}_{3}\right): \delta$ 7.93-7.97 (m, 2H), 7.85-7.92 (m, 4H), 7.68-7.75 (m, 2H), 7.49-7.56 (m, 4H), 7.37-7.40 (m, 1H), 7.29-7.33 (m, 1H), $2.34(\mathrm{~s}, 3 \mathrm{H}), 1.83(\mathrm{~s}, 3 \mathrm{H}) .{ }^{13} \mathrm{C} \mathrm{NMR}\left(75 \mathrm{MHz}, \mathrm{CDCl}_{3}\right): \delta 156.0,148.7,147.7,136.4,135.9$, 135.0, 134.2, 133.7, 133.5, 132.9, 132.8, 129.0, 128.7, 128.5, 128.3, 128.12, 128.09, 128.08, 128.0, 127.5, 127.1, 127.0, 126.7, 126.6, 23.7, 19.6. MS, $m / z(\%) 392\left(\mathrm{M}^{++}-\mathrm{H}, 100\right), 393\left(\mathrm{M}^{+}, 32\right), 378\left(\mathrm{M}^{+}-\mathrm{Me}, 7\right) . \mathrm{HRMS}$ $(\mathrm{ESI}+): \mathrm{m} / \mathrm{z}$ calcd for $\mathrm{C}_{27} \mathrm{H}_{21} \mathrm{CIN}[\mathrm{M}+\mathrm{H}]^{+} 394.1363$; found 394.1371 .

\section{Acknowledgments}

Financial support from the National Science Centre in the form of grant NCN-2012/05/B/ST5/00713 is kindly acknowledged. We also thank Mrs. Krystyna Wojtasiewicz for her valuable technical assistance. 


\section{References}

1. Eicher, T.; Hauptmann S. The Chemistry of Heterocycles: Structures, Reactions, Synthesis and Applications, 2nd ed, J. Wiley \& Sons: New York, 2003.

http://dx.doi.org/10.1002/352760183X

2. Abramowitch, R. A. Pyridines and its derivatives, Supplement; Wiley-Interscience: New York, 1975.

3. Zhao, L.-X.; Moon, Y.-S.; Basnet, A.; Kim E.; Jahng, Y.; Park J. G.; Jeong, T. C.; Cho, W.-J.; Choi, S.-U.; Lee, S. O.; Lee, S.-Y.; Lee, C.|-S.; Lee, E.-S. Bioorg. Med. Chem. Lett. 2004, 14, 1333.

http://dx.doi.org/10.1016/j.bmcl.2003.11.084

4. Hayakawa, M.; Kaizawa, H.; Moritomo, H.; Koizumi, T.; Ohishi, T.; Okada, M.; Ohta, M.; Tsukamoto, S. I.; Parker, P.; Workman, P.; Waterfield M. Bioorg. Med. Chem. 2006, 14, 6847. http://dx.doi.org/10.1016/j.bmc.2006.06.046

5. Palmer, B. D.; Smaill, J. F.; Rewcastle, G. W.; Dobrusin, E. M.; Kraker, A.; Moore, C. W.; Steinkempf, R. W.; Denny, W. A., Bioorg. Med. Chem. Lett. 2005, 15, 1931.

http://dx.doi.org/10.1016/j.bmcl.2005.01.079

6. Perner, R. J.; Lee, C. H.; Gu, Y. G.; Didomenico, S.; Baybut, E. K.; Alexender, K. M.; Kohlhaas, H. L.; Jarvis, M. F.; Kowaluk, E. L.; Bhagawat, S. S. Bioorg. Med. Chem. Lett. 2005, 15, 2803.

http://dx.doi.org/10.1016/j.bmcl.2005.03.098

7. Lawrence, S. A. Amines: Synthesis, Properties and Applications, Cambridge University Press, 2004.

8. Kato, T.; Shoami, M.; Kawase, Y. J. Pestic. Sci. 1980, 5, 69.

http://dx.doi.org/10.1584/jpestics.5.69

9. Masner, P.; Kerkenaar, A. Pestic. Sci. 1988, 22, 61.

http://dx.doi.org/10.1002/ps.2780220107

10. Martina, S. D.; Vesta, K. S.; Ripley, T. L. Ann. Pharmacother. 2005, 39, 854.

http://dx.doi.org/10.1345/aph.1E543

11. Reck, F.; Zhou, F.; Eyermann, C. J.; Kern, G.; Carcanague, D.; loannidis, G.; Illingworth, R.; Poon, G.; Gravestock, M. B. J. Med. Chem. 2007, 50, 4868.

http://dx.doi.org/10.1021/jm070428+

12. Younis, Y.; Douelle, F.; Cabrera, D. G.; Manach, C. L.; Nchinda,A. T.; Paquet, T.; Street, L. J.; White, K. L.; Zabiulla, K. M.; Joseph, J. T.; Bashyam,S.; Waterson, D.; Witty, M. J.; Wittlin, S.; Charman, S. A.; Chibale, K. J. Med. Chem. 2013, 56, 8860.

\section{http://dx.doi.org/10.1021/jm401278d}

13. Duffy, S.; White, K. L.; Shackleford, D. M.; Morizzi, J.; Mannila, J.; Katneni, K.;Bhamidipati, R.; Zabiulla, K. M.; Joseph, J. T.; Bashyam, S.; Waterson, D.; Witty, M. J.; Hardick, D.; Wittlin, S.; Avery, V.; Charman, S. A.; Chibale, K. J. Med. Chem. 2012, 55, 3479.

http://dx.doi.org/10.1021/jm3001373

14. Son, J. K.; Zhao, L. X.;Basnet, A.; Thapa, P.; Karki, R.; Na, Y.; Jahng, Y.; Jeong, T. C.; Jeong, B. S.; Lee, C.S.; Lee, E. S. Eur. J. Med. Chem. 2008, 43, 675. http://dx.doi.org/10.1016/j.ejmech.2007.05.002

15. Zhao, L. X.; Sherchan, J.; Park, J. K.;Jahng, Y.; Jeong, B. S.; Jeong, T. C.; Lee, C. S.; Lee, E. S. Arch. Pharm. Res. 2006, 29, 1091.

http://dx.doi.org/10.1007/BF02969297

16. Błachut, D.; Wojtasiewicz, K.; Czarnocki, Z. Forensi. Sci. Int. 2002, 127, 45.

http://dx.doi.org/10.1016/S0379-0738(02)00121-4 
17. Błachut, D.; Wojtasiewicz, K.; Czarnocki. Z. Forensic Sci. Int. 2005, 152, 157.

\section{http://dx.doi.org/10.1016/j.forsciint.2004.07.018}

18. Błachut D.; Wojtasiewicz, K.; Krawczyk, K.; Maurin, J.; Szawkało. J.; Czarnocki, Z. Forensic Sci. Int. 2012, 216108.

http://dx.doi.org/10.1016/j.forsciint.2011.09.005

19. Błachut, D.; Czarnocki, Z.; Wojtasiewicz, K. Synthesis, 2006, 17, 2855.

20. Błachut, D.; Szawkało, J.; Czarnocki, Z. Synthesis 2011, 21, 3496.

21. Błachut, D.; Roszkowski, P.; Szawkało, J.; Samanta, S.; Czarnocki, Z. Applied Science and Advanced Materials International 2015, 1, 151.

22. Roszkowski, P.; Błachut, D.; Maurin, J. K.; Budzianowski, A.; Górecki, M.; Frelek, J.; Czarnocki, Z. Eur. J. Org. Chem.

http://dx.doi.org/10.1002/ejoc.201600456

23. Lock, E.; Aalberg, L.; Andersson, K.; Dahlén, J.; Cole, M.D.; Finnon, Y.; Huizer, H.; Jalava, K.; Kaa, E.; Lopes, A.; Poortman-van der Meer, A.; Sippola, E. Forensic Sci. Int. 2007, 169, 77. http://dx.doi.org/10.1016/j.forsciint.2006.10.019

24. In Recommended methods for the identification and analysis of amphetamine, methamphetamine and their ring-substituted analogues in seized materials, 2006, United Nations, New York.

25. Krawczyk, W; Kunda, T.; Perkowska, I.; Dudek, D. Bull Narc. 2005, 57, 33.

26. Klinsgberg, E.; The Chemistry of Heterocyclic Compounds. Pyridine and Its Derivatives. Part One, Int. Publisher, Inc. New York, 1960.

27. Hauser, C. R. C.; Eby, J. J. Am .Chem. Soc. 1957, 79, 728.

http://dx.doi.org/10.1021/ja01560a062

28. Letsinger, R. L.; Jamison, J. D. J. Am. Chem. Soc. 1961, 83, 193.

http://dx.doi.org/10.1021/ja01462a038

29. Roszkowski, P.; Błachut. D.; Maurin, J. K.; Woźnica, M.; Frelek, J.; Pluciński, F.; Czarnocki, Z. Eur. J. Org. Chem. 2013, 35, 7867.

http://dx.doi.org/10.1002/ejoc.201301378

30. Toguem, S-M. T.; Fatunsin, O.; Villinger, A.; Langer, P. Tetrahedron Lett. 2011, 52, 3732. http://dx.doi.org/10.1016/j.tetlet.2011.05.044

31. Khera, R. A.; Ali, A. ; Rafique, H.; Hussain, M.; Tatar, J.; Saeed, A.; Villinger, A.; Langer, P. Tetrahedron 2011, 67, 5244.

http://dx.doi.org/10.1016/j.tet.2011.05.036

32. Ibad, M. F. ; Zinad, D. S.; Hussain, M.; Ali, A.; Villinger, A.; Langer, P. Tetrahedron 2013, 69, 7492. http://dx.doi.org/10.1016/j.tet.2013.05.100

33. Ehlers, P.; Hakobyan, A.; Neubauer, A.; Lochbrunner, S.; Langer, P. Adv. Synth. Catal. 2013, 355, 1849. http://dx.doi.org/10.1002/adsc.201300201

34. Old, D. W.; Wolfe, J. P.; Buchwald, S. L. J. Am. Chem. Soc. 1998, 120, 9722. http://dx.doi.org/10.1021/ja982250+

35. Walker, S. D.; Barder, T. E.; Martinelli, J. R.; Buchwald, S. L. Angew. Chem. Int. Ed. 2004, 43, 1871. http://dx.doi.org/10.1002/anie.200353615

36. Nguyen, H. N.; Huang, X.; Buchwald, S. L. J. Am. Chem. Soc. 2003, 125, 11818. http://dx.doi.org/10.1021/ja036947t

37. Reimann, S.; Ehlers, P.; Petrosyan, A.; Kohse, S.; Spannenberg, A.; Surkus, A. E.; Ghochikyan, T. V.; Saghyan, A. S.; Lochbrunner, S.; Kühn, O.; Ludwig, R.; Langera, P. Adv. Synth. Catal. 2014, 356, 1987. 
http://dx.doi.org/10.1002/adsc.201400164

38. Reiman, S.; Ehlers, P.; Sharif, M.; Spannenberg, A.; Langer, P. Tetrahedron 2016, 72, 1083. http://dx.doi.org/10.1016/j.tet.2016.01.010

39. Suzuki, A. Pure Appl. Chem. 1985, 57, 1749.

http://dx.doi.org/10.1351/pac198557121749

40. Bellina, F.; Carpita, A.; Rossi, R. Synthesis 2004, 15, 2419.

41. Schröter, S.; Stock, C.; Bach, T. Tetrahedron 2005, 61, 2245.

http://dx.doi.org/10.1016/j.tet.2004.11.074

42. Kotha, S.; Lahri, K.; Kashinath, D. Tetrahedron 2002, 58, 9633.

http://dx.doi.org/10.1016/S0040-4020(02)01188-2

43. Yang, H. Tetrahedron Lett. 2009, 50, 3081.

http://dx.doi.org/10.1016/j.tetlet.2009.04.040

44. Sheldrick, G.M. Acta Cryst. A 2008, 64, 112.

http://dx.doi.org/10.1107/S0108767307043930

45. Zhang, F.; Zaidi, S.; Haney K. M.; Kellogg, G. E.; Zhang, Y. J. Org. Chem. 2011, 76, 7945.

http://dx.doi.org/10.1021/jo2013669 